\title{
The Viability of the Current Law on Horizontal Restraints
}

\author{
Lawrence A. Sullivan $\dagger$
}

The antitrust tradition is a unique and valued aspect of American political and economic culture. However shopworn, the analogy to a constitution is apt. ${ }^{1}$ The Sherman Act and companion statutes have embodied community ideals about and provided a structure for the governance of America's integrated, continental economy. This traditionthat constitution-is approaching an age that, for any American institution, may be called venerable. It is fitting, then, to examine the current articulation of antitrust and consider how well it can be expected to serve the next century.

My task is to discuss the adequacy of today's law of horizontal restraints for handling the anticipated problems of the 1990's. I accept at the outset Justice Stevens' definition of a horizontal restraint as any "agreement among competitors [about] the way in which they will compete with one another."2 In Part I, I sketch the law of horizontal restraints as it exists today, with emphasis on recent developments along with their problems and implications. In Part II, I try to identify the emerging issues with which that law may have to deal. In so doing, I have occasion to look at some developments in economic theory and related developments. I also examine the business press and other sources of information about economic problems, market reactions, and governmental responses.

On occasions like this it is tempting to indulge in wide-ranging talk about micropolicy. Although I will try to resist, I do have something to say about antitrust values. The radical position-and today the politically salient one-focuses on allocative efficiency. It posits that antitrust should provide rigorous analytical techniques to identify output-restricting market conduct; that is, its norms should deter and its remedies should correct such conduct. ${ }^{3}$ More conservative commentators, myself among them, express their aspirations for antitrust in more conventional

$\dagger$ Earl Warren Professor of Public Law, Boalt Hall School of Law, University of California, Berkeley. B.A. 1948, University of California, Los Angeles; J.D. 1951, Harvard University.

1. Apparently, the first such reference was made by Chief Justice Hughes in Appalachian Coals, Inc. v. United States, 288 U.S. 344, 359-60 (1933).

2. NCAA v. Board of Regents, 468 U.S. 85, 99 (1984).

3. E.g., D. ARmentano, ANTitrust and Monopoly: ANatomy of A Policy Failure (1982); R. Bork, The ANTITRUST PARAdoX (1978); R. POSNer, ANTITRUST LAW: AN ECONOMIC 
terms. ${ }^{4}$ I doubt the capacity of legal institutions to attain great rigor or precision in developing and applying micropolicy. I do, however, think them capable of balancing practically and wisely the range of values that Congress has espoused. Thus, I evaluate current antitrust not solely against microtheoretic learning, but also against antitrust's own sources, against the text and context of its earlier authoritative articulations.

I

The Law of Horizontal Restraints, CirCa 1986

Lawyers and judges used to see the per se rule and the rule of reason as distinct antitrust categories. ${ }^{5}$ They also assumed that the consequences of placing an alleged offense in one category or the other were profound; both the scope of litigation and the odds on how it would come out were drastically affected. Over the past decade, those attitudes have been changing. Looking back to the beginnings of antitrust provides us with a perspective that links these recent developments into a continuum, now nearly a century old.

\section{A. The Early Debate-Objective Norms or Judicial Discretion}

Early antitrust debates focused on the meaning of the phrase, "every .. restraint of trade." Did every mean "every," or only "every unreasonable" restraint? In Standard Oil Co. v. United States, ${ }^{7}$ Chief Justice White, who championed the second view, prevailed. But the alternative position, earlier championed by Justice Peckham, was restated in dissent by Justice Harlan. ${ }^{8}$ Today the Peckham-Harlan contentions are sometimes dismissed as unsophisticated literalism. Viewed that way, Chief Justice White emerges as one trying to give the statute a viability and longevity that a narrow, literalist interpretation could not support.

Perspective (1976); Baxter, Placing the Burger Court in Historical Perspective, 47 ANTITRUsT L.J. 803 (1978); Easterbrook, Workable Antitrust Policy, 84 Mich. L. REv. 1696 (1986).

4. Until the late 1970's a fairly broad consensus prevailed that antitrust had a number of economic objectives. Among these objectives were prices closely related to costs, efficiency, disinterested and nondiscretionary market outcomes, fair market conduct, and economic mobility, as well as related political and social goals. Despite some criticism, e.g., Bork \& Bowman, The Crisis in Antitrust, ForTUNE, Dec. 1963, at 138, the consensus view was found both in the case law, e.g., FTC v. Proctor \& Gamble Co., 386 U.S. 568, 577-80 (1967); Klor's Inc. v. Broadway Hale Stores, 359 U.S. 207, 210-11 (1959); Northern Pac. Ry. v. United States, 356 U.S. 1, 4 (1958); United States v. Aluminum Co. of Am., 148 F.2d 416, 427-30 (2d Cir. 1945), and in the most familiar and frequently cited commentary, e.g., C. KAYSEN \& D. TURNer, ANTITRUST POLICY: AN ECONOMIC AND Legal ANalysis 11-22 (1959); A. Neale, The ANTitrust Laws of the U.S.A. 427-32 (2d ed. 1970).

5. See, e.g., Report of The Attorney General's National Committef to Study tht: ANTITRUST LAWS 12-29 (1955).

6. Sherman Act $\S 1,15$ U.S.C. § 1 (1982).

7. 221 U.S. 1 (1911).

8. Id. at 82 . 
Yet, it does not give sufficient credit to those on either side of the debate to assume that the Peckham-Harlan view was narrow literalism or that the Chief Justice made an obvious, if telling, response. Neither side expressed itself as one might today. Indeed, the Chief Justice did not express himself very well at all. But the basic division between the two sides was their very different conceptions of the proper scope of the judicial role. ${ }^{9}$ Peckham and Harlan searched for fixed and objective norms about what conduct violated the statute. Neither would have greatly resisted judicial participation, informed by practical wisdom and common law tradition, in identifying that conduct. But once identified, they thought the legal norms should be expressed at an intermediate level of generalization, in the kind of language both that courts are accustomed to using when telling the business community what it may and may not do, and that the business community understands. A Peckham-Harlan rule might read like this: It is an illegal restraint of trade to combine with your competitor; or to divide territories or fix prices with him; or to sell below cost in the territory of a competitor that has refused to enter into a combination. Chief Justice White, by contrast, was more impressed by the great complexity of the economy and less timid about the capacity of courts to sort things out correctly in particular cases, so long as they kept the legal norms sufficiently general.

Though White had the votes in Standard Oil, the dialectic between supporters of specific and general antitrust norms has never ended. One thinks immediately of United States v. Socony-Vacuum Oil Co., ${ }^{10}$ which refined the Peckham-Harlan view of fixed objective norms, and of Board of Trade $v$. United States, ${ }^{11}$ which supported sweeping judicial discretion. True, after the canon was expanded to include these extremes, a Januslike stability seemed to reign; the prevailing compromise between the early 1940's and the mid-1970's took a rule-oriented approach in preidentified sets of circumstances, ${ }^{12}$ and an open-ended discretionary approach in all others. Yet, debate continued sub rosa in contests about how particular conduct should be characterized. ${ }^{13}$

9. See W. ANdersen \& C. Rogers III, Antitrust LaW: Policy and Practice 18-28 (1985) (contrasting excerpts from the majority and minority opinions).

10. 310 U.S. $150,210-28$ (1940).

11. 246 U.S. 231, 238 (1918).

12. In one opinion by Justice Black, the per se category was held to include price fixing, division of markets, group boycotts, and tying arrangements. Northern Pac. Ry. v. United States, 356 U.S. 1,5 (1958).

13. Compare, e.g., United States v. Socony-Vacuum Oil Co., 310 U.S. 150 (1940) (agreements by competitors to take turns buying distressed oil to take it off the market deemed price fixing) with Appalachian Coals, Inc. v. United States, 288 U.S. 344 (1933) (legality of an agreement to establish prices among competitors through a common selling agent held to turn on its unproved effects). The debate's focus on issues of characterization may have indicated that the classical per se-rule of reason distinction could not be expected to remain forever sacrosanct. Interestingly, Article 85 of 
Though it drew little attention during that period, one early case, United States v. Addyston Pipe \& Steel Co. ${ }^{14}$ modeled a compromise between the two views that did not split and share the antitrust terrain. In that case, Judge Taft, then a circuit judge, suggested an approach countenancing an inquiry, though usually a limited one, in almost all cases. This inquiry would focus on whether competitive harm was intended or achieved, whether competitive benefits were accomplished by the restraint, and most importantly, whether less restrictive ways could achieve the benefits. Today-and this is most evident in Justice Stevens' opinions-the Court is again moving toward such a synthesis; the Peckham-Harlan thesis and the White antithesis are both reflected in the Court's higher integration of the demands for predictability and manageability on the one hand and for particularized accuracy on the other.

\section{B. The Implosion of Rules \& Discretion: The Modern Trend}

The modern synthesis begins with National Society of Professional Engineers v. United States. ${ }^{15}$ Whether classifled as a per se or a rule of reason decision, it teaches that a court may consider only limited factors in antitrust analysis; any matter not bearing on whether an alleged restraint increases or decreases competition is for legislative, not judicial, attention. For the first time, a real structure was imposed on the undisciplined shopping list-nature of the business, history of the restraint, and all the rest-that Justice Brandeis had tendered to juries in Board of Trade v. United States. ${ }^{16}$ More than this, the Court rejected the opinion's implication that courts applying the rule of reason could treat a range of social betterments, such as the quietude achieved by concerted agreements as to closing hours, as a benefit offsetting competitive harm. ${ }^{17}$

Such a narrowing of the concept of benefit greatly reduces the distance between per se and rule of reason analysis for horizontal restraints. Those sharing the Peckham-Harlan view had feared the rule of reason would allow courts to evaluate any and all social betterments against adverse competitive impact-a task conventionally thought of as legislative in character. But the Supreme Court eliminated this dangerous discretion by confining judicial inquiry solely to the effect of a practice on competition, and by characterizing the conventional per se offenses not

the Treaty of Rome, the EEC provision forbidding concerted practices restricting competition, though modeled in a rough sense on section 1 of the Sherman Act, has never been construed to entail a strict per se doctrine. See V. Korah, COMPETITION LAW OF BRITAIN aNd the COMmon MARKET $\S 9.3 .2$ (3d ed. 1982).

14. 85 F. 271 (6th Cir. 1898), modified and aff'd, 175 U.S. 211 (1899).

15. 435 U.S. 679 (1978).

16. 246 U.S. 231, 238 (1918).

17. Professional Eng'rs, 435 U.S. at $689-90$. 
as separate species of restraints, but as illustrations of conduct that injures competition.

Of course, a full catalog of issues remain. When is competition hurt? Some say it is hurt only when output reduction and profit enhancement are shown. ${ }^{18}$ Others say it is hurt whenever there is a significant injury to the competitive process-the noncoercive way in which free market rivalry is ideally expressed. ${ }^{19}$ What constitutes an offsetting benefit to competition? Health and general welfare are out, ${ }^{20}$ but how about corrections of market failures? The Professional Engineers Court rejected as a defense the claim that the elimination of competition among engineers was necessary to ensure industry safety. ${ }^{21}$ But might the Court in other settings be open to more concrete showings that discernable market failures can be concertedly corrected in ways leaving room for ample competition? ${ }^{22}$ Increased efficiency counts as a benefit, no doubt, but how are the calculations to be done? Could a technological cost reduction, concertedly achieved, trump cost increases and income transfers due to resulting market power? ${ }^{23}$ Must a rule of reason plaintiff always prove market power, or is it enough to show a practice that, like a price agreement, will hurt competition if it has any effect at all? ${ }^{24}$ Who has the burden of proving what, and when do burdens shift? ${ }^{25}$

One's approach to these issues depends less upon knowledge than upon beliefs and values. ${ }^{26}$ Some people fear excesses of private power

18. See, e.g., authorities cited supra note 3 .

19. See, e.g., Fox, The Modernization of Antitrust: $A$ New Equilibrium, 66 CORNELl L. REv. 1140 (1981); cf. Scherer, The Posnerian Harvest: Separating Wheat from Chaff (Book Review), 86 YALE L.J. 974, 980-81 (1977) (criticizing Posner's failure to recognize diffusion of economic power as one of the goals of antitrust).

20. This is the minimal teaching of Professional Eng'rs, 435 U.S. at 693-94.

21. Id.

22. Concerted action to correct market failures, especially failures in which consumers are thought to be targets for overreaching due to lack of information, are among the favored problems raised by the leading course books. E.g., P. AREEDA, ANTITRUST ANALYSIS \\ 346, 348, 349, 351 (3d ed. 1981); M. Handler, H. Blake, R. Pitofsky \& H. Goldschmid, Trade Regulation 321, Problem 7 (2d ed. 1983).

23. Compare Williamson, Economies as an Antitrust Defense: The Welfare Tradeoffs, 58 AM. ECON. REv. 18 (1968) with Fisher \& Lande, Efficiency Considerations in Merger Enforcement, 71 Calif. L. Rev. 1580 (1983).

24. See NCAA v. Board of Regents, 468 U.S. $85,109-110$ (1984) (under rule of reason plaintiffs do not have to prove the defendant's market power where there is an agreement not to compete in price or output); see also FTC v. Indiana Fed'n of Dentists, $106 \mathrm{~S}$. Ct. 2009 (1986).

25. See Harris \& Jorde, Antitrust Market Definition: An Integrated Approach, 72 CALIF. L. REv. 1 (1984); Horizontal Merger Guidelines of the National Association of Attorneys General, 52 Antitrust \& Trade Reg. Rep. (BNA) (Special Supplement, March 12, 1987) (tracking the market definition methodology developed by Harris and Jorde in their article).

26. Harris \& Sullivan, Horizontal Merger Policy: Promoting Competition and American Competitiveness, 31 ANTITRUST BULL. 871 (1986) identifies several categories of antitrust ideology: (1) "mainstreamists" who value well-functioning markets for the efficiencies they can yield, but are aware of their limitations; (2) "marketeers" who believe that all markets operate efficiently and that 
more than excesses of public power, and think power is used more knowledgeably and wisely when exercised by those close to people affected by it. Others hold an opposite view. Some people are acutely aware of the deficiencies of markets and regard government, despite its many failures, as a useful institution for making markets work better. Others view markets as extraordinarily effective, self-correcting institutions; they think that when government interferes it is either (1) because government has been fooled (or captured) by those who want to manipulate markets to their own profit, (2) because government bureaucrats find it personally profitable to exercise governmental power, or (3) because government, though acting for benign purposes, has made a mistakesince, even when government lays its hand on the market in a good faith effort to serve the commonweal, it is likely to make things worse.

Some think the most important economic question is how to achieve the maximum output from the available input. ${ }^{27}$ According to this view, questions about distribution or about the size, scope, and quality of life in the wealth-producing bureaucracies are trivial by comparison. ${ }^{28}$ Others are convinced that distributional issues are at least as important as efficiency issues. ${ }^{29}$

government intrusion into these markets is counterproductive; (3) "corporateers" who assert that American businesses should be free to compete without interference; and (4) "statists" who adhere to the views of Galbraith and Thurow, seeing large corporate organizations with vast market shares as essential for effective competition.

27. See, e.g., Easterbrook, supra note 3.

28. Id. at 1702-05. Easterbrook does not claim, as do some commentators, that it would be irrational to conclude "some people get more utility out of money than others." He insists only that Congress, not courts, must make such value choices. But of course Congress did make that choice; it decided that courts were to intervene to keep monopolists and cartelists from taking monopoly returns. Rather than recognize this simple and obvious distributional goal of the Sherman Act, Easterbrook, like Bork, regards references to excessive prices as aimed at the allocative concern"efficiency (or its close proxy consumers' welfare) . ..." Id. at 1703-04. For a review of the welfare economics literature about interpersonal differences in utility and the debate between the ordinalists (who thought rational redistributional choices could be made) and cardinalists (who thought otherwise), see Cooter \& Rappoport, Were the Ordinalists Wrong About Welfare Economics?, $22 \mathrm{~J}$. ECON. LIT. 507 (1984).

29. Estimates of the social costs of market power that measure only the dead weight loss due to allocative inefficiency ignore (1) expenditures made by firms to gain or protect market power, such as a product development strategy that would be rejected by the firm in favor of more efficient ones, except for its tendency to frustrate rivals ("rent chasing"); (2) wasteful failure to reduce costs that could easily be reduced and that would be reduced under the spur of greater competition (" $x$ inefficiencies"); and (3) the transfer of wealth from consumers to the monopolist, the distributional distortion measured by the monopoly profit. See Kaplow, The Accuracy of Traditional Market Power Analysis and a Direct Adjustment Alternative, 95 HARV. L. REv. 1817 (1982); Lande, Wealth Transfers as the Original and Primary Concern of Antitrust: The Efficieney Interpretation Clallenged, 34 Hastings L.J. 67 (1982). Cowling \& Mueller, The Social Costs of Monopoly Power, 88 EcoN J. 727,739 (1978), estimates the total losses from market power as ranging from $4 \%$ to $13 \%$ of value added in manufacturing. Total losses can be even higher in highly concentrated industries with product differentiation. See Parker \& Connor, Estimates of Consumer Loss Due to Monopoly in the U.S. Food-Manufacturing Industries, 61 AM. J. AGRIC. EcoN. 626 (1979) (consumer losses 
Some people think that an economy of numerous independent decisionmakers, an economy open to considerable mobility, is preferable even at modest risk to efficiency. Some of this persuasion see a positive relationship between, on the one hand, an economy in which many have a personal stake and a degree of control and, on the other, a democratic and liberal polity. Others of them prefer an unconcentrated economy for its own sake-they are more comfortable in small organizations than large; they value the sense of freedom and empowerment that they associate with an economy where workers become entrepreneurs, an economy that invites entry and change. ${ }^{30}$

Most antitrust issues, in short, are political in nature; they are not matters on which consensus can be achieved by turning them over to technocrats.

I do not mean to imply the subjectivist view that values, like tastes, are indisputable. In some contexts one can express rational reasons for choosing one value over another. This is especially true in antitrust, where Congress and courts, as well as academic commentators, have frequently expressed their values and their reasons for them. My point here is two-fold: first, much of the disagreement about the meaning and significance of particular cases is traceable not to differences in either perception or analysis, but to different value choices; second, there are institutional concerns that are shared by those who espouse quite different values. Many of these shared concerns are judgments about the appropriate role of court and legislature and of rule and discretion in implementing the value choices from which various approaches to antitrust arise. Hopefully, consensus can be achieved concerning what a court owes to precedent, and how much discretion it should exercise, even if division prevails over solutions to value-laden substantive issues.

The Court's most recent cases involving horizontal restraints, Broadcast Music, Inc. v. CBS, ${ }^{31}$ Arizona v. Maricopa County Medical

estimated at $26 \%$ of value added where the weighted average concentration rate for the market was $52 \%$ of these losses, $29 \%$ were attributable to income redistribution, $68 \%$ to $x$-inefficiencies, and a mere $3 \%$ to deadweight social welfare loss). Among the policy documents recently emphasizing the importance of distributional issues is National Conference of CATHolic Bishops, Economic Justice for All: CATHolic Social Teaching and the U.S. Economy (1986).

30. Policy consensus notably broader than those expressed by Chicago theorists is found, for example, in the articles cited supra in notes 19 \& 29, and also in L. KAPLOW, ANTITRUST, LAW \& ECONOMICS, AND THE COURTS (Program in Law and Economics, Harvard Law School, Discussion Paper No. 21, 1986); Hovenkamp, Antitrust Policy after Chicago, 84 MicH. L. REv. 213 (1985); Kaplow, Extension of Monopoly Power Through Leverage, 85 CoLUM. L. REv. 515 (1985); Williamson, Antitrust Enforcement: Where It's Been, Where It's Going, 27 ST. LoUIS U. L.J. 289 (1983); Fox, The Politics of Law and Economics in Judicial Decision Making: Antitrust As a Window, 61 N.Y.U. L. REv. 554 (1986); Spivak, The Chicago School Approach to Single Firm Exercises of Monopoly Power: A Response, 52 ANTITRUsT L.J. 651 (1983).

31. 441 U.S. 1 (1979). 
Society, ${ }^{32}$ NCAA v. Board of Regents, ${ }^{33}$ and FTC v. Indiana Federation of Dentists $^{34}$ are essays on some of these questions. Each attempts to fine tune the emerging integration of discretion and rule. Yet seldom is any issue fully clarified; nor should we expect that it will be.

Broadcast Music, to be sure, models one important proposition. If a practice "facially appears to be one that would ... almost always tend to restrict competition and decrease output," it is unlawful. ${ }^{35}$ The restraint is thus "per se" wrong if, given its particulars and its setting, those adverse characteristics appear on its face. If not, then a fuller analysis is required to determine whether a competitive injury is occurring or an efficiency is being attained.

Given the obvious potential for reducing transaction costs through joint marketing of copyright packages, and given also that individual licensing was not foreclosed, the Court ruled that the restraint in Broadcast Music was not facially invalid. ${ }^{36}$ Competition might well be helped rather than hurt. A whole new sphere of marketing activity was opened up-in a sense, a new product was created. Moreover, this was achieved without ousting the old product, individual copyright licensing; this old way of doing business remained available to buyers and sellers who preferred it. Apparently, too, the arrangement was free of coercion; no buyer or seller was obliged to come into a packaged songs market, nor to stay out of the individual song market. ${ }^{37}$

In his dissent, Justice Stevens did not disagree with the majority's analysis so much as with its stopping point. ${ }^{38}$ Like the majority, Stevens would have rejected a per se characterization, but he would not have remanded the case to the trial court. Rather, he would have resolved the rule of reason inquiry on the basis of the facts already before the Court. He would have found defendants liable because even those limited facts plainly showed a less restrictive means available for attaining the efficiencies that had so impressed the majority. ${ }^{39}$ Though the majority rejected it, Justice Stevens' solution represented another refinement in the Peckham-Harlan tradition favoring fixed objective norms.

Despite their different stopping points, however, the majority and the minority in Broadcast Music were moving in the same direction. Both opinions signal the implosion of rule of reason and per se analysisof discretion and self-executing rule. Both identify circumstances in

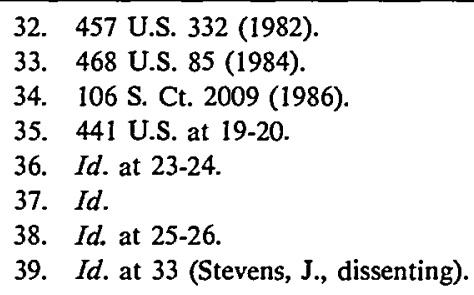


which a court should decide a case on the basis of a mid-level norm and a truncated record. The majority would not countenance that response when the facial inquiry of a restraint suggests not only injury to competition, but offsetting efficiencies as well. Justice Stevens would go a step further, arguing that a violation should be adjudicated even when both are suggested if it is facially apparent that the efficiencies could be obtained by less harmful means. In his view, it wastes resources and confuses the legal norms to remand such a case for more elaborate factual inquiry. ${ }^{40}$ In contrast to Justice Stevens, the majority defined a more narrow range of situations in which appellate courts would make the ultimate decision, requiring full inquiry by the trial court whenever both injury to competition and increased efficiency are possible effects of defendant's conduct. Interestingly, the majority gives little guidance for balancing efficiency and harm once the record is expanded. Is each district court to have a free hand in determining both whether an efficiency is apparent and how much weight it carries? Is the "less restrictive alternative" approach, which Justice Stevens found dispositive, to have a large role, a limited one, or none at all? Perhaps the majority simply wanted a full record before metering efficiency and competitive injury against each other. ${ }^{41}$

Broadcast Music, then, intensifies the synthesis between the Peckham-Harlan and the White conceptions of antitrust analysis. Extending Professional Engineers, it narrows the distinction between per se and rule of reason analysis. The majority asserts that while per se analysis can yield greater simplicity and certainty, it should not be permitted to do so at too great a cost in economic efficiency. ${ }^{42}$ The dissent agrees, but insists that while the rule of reason can yield precision and accuracy, it should not be permitted to do so at too great a cost in delay, uncertainty, and litigation. ${ }^{43}$

Broadcast Music provides, or at least begins, a framework for modern horizontal restraint analysis. Yet, questions about what constitutes a competitive harm or a competitive benefit as well as related questions about institutional assignments remain. True, the Court stressed the sig-

40. Id. at $26 \&$ n. 4 .

41. Concerning the difficulties of comparing an efficiency gain with an increase in market power that might yield $x$-inefficiencies, a dead-weight loss, and an income transfer from consumers to firms, see Fisher \& Lande, supra note 23; see also A. FISHER, F. JOHNSON \& R. LANDE, Mergers, Market Power, and Property Rights: When Will Efficiencies Prevent Price INCREASEs? (Federal Trade Commission, Bureau of Economics Working Paper No. 130, 1985).

42. This aspect of the holding has been stressed elsewhere. See Hutchinson, Antitrust 1984: Five Decisions In Search of a Theory, 1984 SuP. CT. REv. 69, 110; Sullivan \& Wiley, Recent Antitrust Developments: Defining the Scope of Exemptions, Expanding Coverage, and Refining the Rule of Reason, 27 UCLA L. Rev. 265, 330-36 (1979).

43. Broadcast Music, 441 U.S. at 26 \& n.4 (Stevens, J., dissenting). 
nificance of output reduction and efficiency, but it said nothing about how to compare the two and nothing about other historic concerns.

Some might contend that the majority's emphasis on output reduction and the importance of efficiency aligned the Court with the radical Chicago view, which identifies the loss of allocative efficiency as the sole antitrust harm (and one that can be trumped even by offsetting productive efficiencies when these are achieved by a restraint that reduces output). ${ }^{44}$ Such a reading of Broadcast Music, however, probably owes more to aspiration than to critical parsing of the text ${ }^{45}$ and context. ${ }^{46}$ No one who values antitrust at all doubts the significance or even the primacy of the harm of output reduction (which always yields a price increase and a transfer of wealth from consumers to cartelists or a monopolist); nor does anyone question that, other things being equal, the more efficient structure or conduct is the preferable one. The disputable value questions concern such matters as whether the income transfer from consumers to producers or the loss in allocative efficiency is most relevant, and how those harms are balanced against gains in productive (or dynamic) efficiency.

Chicago theorists view Arizona v. Maricopa County Medical Society $^{47}$ as a regression from Broadcast Music. ${ }^{48}$ I see it more as a tilt toward the Stevens end of the continuum between rule and discretion. The Maricopa majority does seem to say that once a price agreement (maximum or minimum) among competitors has been shown without

44. This seems to be the view taken in Easterbrook, supra note 3, as well as in Hutchinson, supra note 42 .

45. On its facts, a tradeoff of possible allocative efficiency loss against productive efficiency gain was obviously involved in Broadcast Music. But nothing in the Court's language implies that these concerns, so evident in the case before it, are the law's only concerns.

46. As Kaplow points out, it was to Northern Pac. Ry. v. United States, 356 U.S. 1 (1958), a case which explicitly recognized a wide range of antitrust concerns, that the Broadcast Music opinion cited to support its references to output restriction and efficiency. L. KAPLOW, supra note 30, at 43. Advancing productive efficiency is an antitrust goal that can be factored into analysis. This is especially true for mergers, since productive efficiency fails when markets become concentrated. Also, in some instances it may be possible to identify the specific effects on productive efficiency of either specific mergers or specific loose-knit arrangements. Dynamic efficiency (technological progress), by contrast, bears a highly complex and considerably indeterminate rclationship to market structure and conduct, thus making it much more difficult to factor into analysis at our present stagc of theoretical learning and empirical information. See W. BALDWIN \& J. SCOTT, MARKET Structure and Technological Change (1987) for a comprehensive survey of the literature.

The importance of productive efficiency as an antitrust goal is emphasized in Harris \& Sullivan, supra note 26. Productive and dynamic efficiency are both cmphasized in F.M. Scherer, Antitrust, Efficiency, and Progress, and in J.F. Brodley, What is Efficiency and Technological Progress of thc Sort that Antitrust Should Foster, and How Should Antitrust Measure and Promote It? (papers delivered at the Airlie House Conference, The Antitrust Alternative, March 28, 1987).

47. 457 U.S. 332 (1982).

48. See, e.g., Easterbrook, Maximum Price Fixing, 48 U. CHI. L. REv. 886 (1981) (published before the Maricopa decision and arguing against the result the Court later reached); $c f$. Hutehinson, supra note 42 , at 101-02. 
integration of any other aspect of their operations, the facial inquiry is over. ${ }^{49}$ But the specific reasoning of the majority may be as significant as its more sweeping statements.

The defendants in Maricopa argued that their arrangement had an adequate procompetitive benefit; maximum charges for particular medical services allow insurers to calculate their exposure more accurately and thus set lower insurance rates. The majority rejected that specific contention, but did not reject the pertinence of that argument in principle; rather it found the argument unpersuasive on the facts at hand. Though it stressed the possible harms of maximum price fixing, the majority implicitly recognized its possible competitive benefits. But it found there were less restrictive ways, at least nearly as efficient, that insurers could have used to fix a maximum-ways that threatened no competitive injury at all..$^{50}$ Given that the majority gave heed to all these factors, its decision in Maricopa looks not like a knee-jerk per se reaction, but like an analytically enhanced approach to facial illegality. Indeed, it quite resembles the truncated rule of reason analysis Justice Stevens urged on the Court in Broadcast Music.

To shepherd the Maricopa agreement past the enhanced per se rule (or truncated rule of reason) toward which Broadcast Music pointed, one would need to show several things: first, that defendants, by jointly fixing a maximum price, performed an economic function that could not be effectively performed without joint pricing; second, that their pricing agreement impeded as few alternative transactions as possible; and third, that their program did not coerce the participation of any physician who preferred to price on her own. The Maricopa opinion tells us, and justifiably so, that this standard was not met; insurers could have investigated and set maximums fully adequate for their purposes without drawing doctors into a price agreement.

The Chicago objection to Maricopa, then, probably has to do with the implications in that case about the basic assumptions that should inform judicial inquiry into the marketplace. Here Maricopa does diverge from Chicago analysis.

Though seldom well articulated, there is a theory about the internal workings of firms underlying the rigorous kind of microtheorizing associated with Chicago. It posits that each firm is profit maximizing, and hence cost minimizing, irrespective of the structure of the inarket in which it is operating, the stability of conditions currently prevailing in that market, or the status of relationships with firms in adjacent markets. ${ }^{51}$ Under this theory, cost reduction explains any conduct encoun-

49. 457 U.S. at 351.

50. Id. at 353 .

51. The assumption that even firms in concentrated markets are cost minimizers is implicit or 
tered in any market. To Chicago analysts, if health insurers want doctors to compute a group maximum price, then price fixing must be the low-cost solution to providing health insurance; otherwise it would not be done. Therefore, the burden should be on plaintiffs to prove precisely what competitive harm, if any, results from the practice and to show that this harm outweighs any cost reduction to the insurers. It is this assignment of burdens-and, implicitly, its underlying theory-that the majority in Maricopa rejected.

Whether rejection of the cost-reduction theory was a sound call on the Maricopa facts is, perhaps, debatable. Firms that must sell their outputs in competitive markets may well be under severe pressure to cut costs. Absent other explanations, it may well be appropriate to attribute their conduct to this goal. Thus, if the insurance market in Maricopa was competitive, this cost-reduction theory might have been rightly applied here. Still, Maricopa is to be valued for not having accepted the general and unqualified Chicago theory. Firms in concentrated markets are not under implacable pressure to tame their costs. Their managers usually have considerable discretion over whether to use the rewards of market power to pay suppliers, to simplify purchasing, to keep labor peace, to build entry-deterring excess capacity, or to benefit stockholders by vigorously minimizing input, labor, and other costs. ${ }^{52}$

So much and no more can I coax from Maricopa. I must go beyond it for answers to the remaining questions about the new rule-discretion

explicit in most of the Chicago literature. See, e.g., the contributions of McGee, Brazen, Demsetz and Weston to Industrial Concentration: THE New Learning (H. Goldschmid, H. Mann \& J. Weston eds. 1974); see also Leitzinger \& Tamor, Foreign Competition in Antitrust Law, 26 J.L. \& ECON. 87 (1983); Peltzman, The Gains and Losses from Industrial Concentration, 20 J.L. \& EcoN 229 (1977). As a theory of the firm, such a view is not only simplistic but, given the extent to which theory has moved beyond it, seems almost quaint. See, e.g., the literature review in Marris \& Mueller, The Corporation, Competition and the Invisible Hand, 18 J. ECON. LIT. 32 (1980); see also Harris \& Sullivan, supra note 26 , at $898-903,915-23$.

52. The contrary assumption ignores both rent-chasing expenditures (whether aimed at building barriers or raising rivals' costs) and $x$-inefficiencies; it thus partakes of the same error as assuming that the only social cost of market power is a loss in allocative inefficiency. See supra note 29. In fact, convincing data shows that firms with market power both (1) make excessive payments to labor, see R. Freeman, Unionism, Price-Cost Margins, and the Return to CaptTal (National Bureau of Economic Research Working Paper No. 1164, 1983); Salinger, Tobin's Unionization, and the Concentration-Profits Relationship, 15 RAND J. ECON. 159 (1984), and (2) tend to maintain excess capacity, see R. HALL, CHRONIC EXCESS CAPACITY IN U.S. INDUSTRY (National Bureau of Economic Research Working Paper No. 1973, 1986).

Substantial episodic and impressionistic evidence also shows that firms in concentrated markets must and can cut costs when they encounter new competition resulting from technological change, deregulation, or international market integration. E.g., Hampton \& Cook, Detroit Raises the Ante for Parts Suppliers, Bus. WK., Oct. 14, 1985, at 94 (auto industry rearranges contracts with suppliers to gain efficiencies and cost savings); Green, Middle Managers Are Still Sitting Ducks, Bus. WR., Sept. 16, 1985, at 34 (U.S. businesses laying off middle management to reduce costs); U.S. Auto Makers Reshape for World Competition, Bus. WK., June 21, 1982, at 82; see generally T. PETERS \& R. Waterman, In Search of Excellence (1982). 
continuum. What constitutes competitive injury? What constitutes an offsetting benefit? What kind of inquiry is called for where factual complexity forecloses facial resolution? To pursue these questions, I turn to NCAA v. Board of Regents. ${ }^{53}$

In $N C A A$, the plaintiffs, colleges with popular football teams, challenged the NCAA's control over football broadcasting. Faced with elaborate and long-standing NCAA regulation of intercollegiate sports (including mandatory joint television marketing of NCAA football) the Court, on the ground that some degree of cooperation is needed to market the product at all, rejected a per se conclusion and moved to rule of reason analysis. But just as per se or facial inquiry was enhanced in Maricopa, so here, rule of reason inquiry was narrowed and constrained. The majority thus fully accepted the synthesis that Justice Stevens had been forging between rule and discretion: given the need for some restraints, no particular restraint within the package ought to be labelled per se unlawful; nonetheless, when it becomes clear even from a fairly surface analysis that one or more of the restraints unnecessarily injures competition, all inquiry should end. ${ }^{54}$ The rule of reason no longer need signify endless inquiry into cross elasticities, supply substitutability, scale economies, transaction costs, and learning curves. On the contrary, it should now allow one to put an antitrust theory of liability or justification into terms that a country lawyer can understand. When that is accomplished, judicial inquiry can be easily conducted and quickly brought to an end.

The NCAA Court appropriately focused primarily on consumer welfare in its truncated rule of reason analysis. But coercion and reduced mobility were also significant factors. The Court found the restraints illegal because: (1) the NCAA plan reduced the total number of games televised and increased the prices paid for games; ${ }^{55}$ (2) the plan prevented colleges producing games with mass appeal from either obtaining a share of joint revenues commensurate with their market attractiveness or leaving the association and marketing on their own; ${ }^{56}$ and (3) the plan prevented small colleges from independently marketing local games, thus depriving local stations of entry into college football broadcasting. ${ }^{57}$

In some quarters, Justice Stevens's opinion, joined by six other justices, received warm praise. ${ }^{58}$ But it has also been criticized on a variety

\footnotetext{
53. 468 U.S. 85 (1984).

54. Id. at 103 .

55. Id. at $105 \&$ n. 29.

56. Id. at 94-95. Ponsoldt, The Unreasonableness of Coerced Cooperation: A Comment Upon the NCAA Decision's Rejection of the Chicago School, 31 ANTITRUST Bull. 1003 (1986), emphasizes the importance of this aspect to the Court's decision.
}

57. 468 U.S. at 118 n.62.

58. E.g., Ponsoldt, supra note 56. 
of grounds. ${ }^{59}$ One charge is that the Court made a rule of reason call at the appellate level when the preconditions did not warrant findings of price enhancement and output restriction. ${ }^{60}$ Other charges are that the Court misdefined the market, ${ }^{61}$ and that it lacked a consistent and coherent theoretical framework. ${ }^{62}$ An examination of these criticisms may give dimension to the developing conception of the truncated rule of reason.

Even though the Court found joint pricing, its refusal to apply a per se rule was anything but revolutionary for the very reason specified in the opinion. The record showed no conventional price fixing agreement; the NCAA is no conventional cartel. Some integration had taken placeintegration of a fairly complex kind. ${ }^{63}$ Ever since Appalachian Coals, Inc. $v$. United States, ${ }^{64}$ analysts giving any credence to judicial method have known that integration going beyond mere agreement on price requires at least a truncated inquiry to determine whether benefits exceed harms. ${ }^{65}$ Does the integration promise efficiencies? Is joint price setting reasonably necessary to achieve them? Are the restraints excessive? Are market participants being coerced to participate?

Nor should one be troubled that the NCAA Court found no per se violation without a showing of market power. Integration among firms does preclude automatic characterization of the conduct as price fixing, but it does not necessarily mean that the conduct does not harm competition unless engaged in by firms exercising power. Some concerted conduct not amounting to classic cartelization may fall manifestly short of promising competitive benefit. It may constitute or facilitate neither efficiency nor new product or market development. It may display no help-

59. The most comprehensive and thorough critique from a Chicago perspective is that in Hutchinson, supra note 42 , at 98-112.

60. Hutchinson, supra note 42 , at 108. Justice Stevens did conclude that the plan increased the prices paid by the networks and reduced the number of games televised. NCAA, 468 U.S. at 105 \& n.29. Hutchinson, like Justice White in dissent, Id. at 129 , thinks this was the wrong measure of output (and hence price effect)-that the right question was not number of games, but total viewership. While Justice White claimed he could facially determine that output, properly conceived, was increased, Hutchinson seems to claim only that without a hearing on market definition and power, one could not tell whether output was reduced. Hutchinson, supra note 42, at 111.

61. Hutchinson, supra note 42 , at 108. This criticism is, of course, related to the above criticism concerning the proper measure of output. The issue, in essence, was whether college football for TV (which NCAA dominated) was a market, or whether the market was TV programming material (of which NCAA had a very small share).

62. Id. at 112 .

63. League teams work together in developing rnles and schedules, coordinating the recruiting process, hiring and assigning referees, etc.

64. 288 U.S. 344 (1933).

65. Indeed, though expressing doubt about the ultimate conclusion in Appalachian Coals, Justice Stevens's opinion in Professional Engineers underscores the doctrinal wisdom of that very aspect of the case. 435 U.S. $679,681-99$ (1978). 
ful relationship to competition on the merits. Indeed, some such conduct, like price fixing itself, may have no apparent utility to its sponsors save that it will, if successful, reduce the competitive pressures they might otherwise feel.

Suppose, for instance, that two competitors, manufacturers of farm implements, have been recently losing shares to an innovative, price-cutting entrant. Suppose that they concertedly bribe labor union officials to foment a strike against the maverick firm. It would make no sense to require a showing of market power-with expensive and time-consuming contentiousness about international competition, potential entrants and the like-as a precondition to enjoinmg, punishing, or awarding damages caused by such a blatantly anticompetitive conspiracy. Section 1 of the Sherman Act clearly forbids such conduct regardless of market power.

Conduct, like power, can be arrayed on a continuum. ${ }^{66}$ Some concerted conduct may improve competition even when engaged in by firms with power; it inay, for example, mitigate a significant market failure. Other conduct may be risky when the cooperating firms have market power, but potentially beneficial when they do not. But there is also conduct that is coercive, and thus harmful, regardless of power, and that has no potential for improving competition. To be sure, if a court can evaluate the competitive effect of a practice only after a finding of market power, a hearing on that issue should be held. But a sensible antitrust policy should not insist on extensive inquiries when they are unlikely to facilitate a wise resolution of the dispute.

In $N C A A$, a hearing on market power would have been a defendantprotecting ritual. Suppose defendants had succeeded in proving at trial that for network and advertising purposes, movies, serial reruns, and other programming were adequate substitutes for Saturday afternoon college football-that is, the NCAA had little power to raise prices above a competitive level. Despite this, the NCAA restrictions would remain coercive and, in this sense, blatantly injurious to competition. Some colleges were highly successful producers-their games had great market appeal. Others were less successful. The successful colleges were eager to obtain for themselves the big rewards that an unconstrained market would yield. But the restrictions locked them into a system that forced them to share their market success with schools that produced less saleable products. Not only were plaintiffs coerced, but market incentives to excel in producing football were distorted. ${ }^{67}$

It is not an answer that the internal arrangements among powerless

66. This point is sometimes stressed in discussions of attempts to monopolize. See, e.g., W. ANDERSEN \& C. ROGERS III, supra note 9, at 239-42.

67. One might argue as an original proposition that institutions of higher learning ought not to be given appealing incentives to produce highly marketable football, but that argument goes to 
joint venturers present no antitrust issue. ${ }^{68}$ These were not cost and profit sharing arrangements freely assented to after open negotiation. Regardless of whether competition from substitute programming deprived the NCAA of market power in selling amateur football to TV stations, the NCAA clearly controlled entry into the business of producing and selling that particular product. Unless one envisages a state university as capable of shifting disinterestedly and with equal success from producing football to producing soap operas or other programs, the NCAA clearly had, and was exercising, power to limit drastically the economic opportunity and mobility of the larger colleges that wanted to independently market their product nationally. The NCAA was also foreclosing some small colleges and local stations from turning to each other; the former to market their product in markets more suited to their size, and the latter to develop potentially profitable local programming.

The Stevens opinion for the majority in NCAA and the Stevens dissent in Broadcast Music are quite similar. In both he applied a truncated rule of reason and identified a violation not dependent on market power. In both he saw the harm as outweighing the claimed benefits because the benefits could be achieved in a less restrictive way. In both he saw a distortion of the price system-some participants got more and some got less than their products would bring in a competitive market. What differentiates the cases, and the reason Stevens had six Justices with him in $N C A A$ and none in Broadcast Music, is that in the latter the seemingly disadvantaged copyright licensors came in of their own choice, and remained free to trade outside as well. The rights of the composer as well as of the licensee were protected. Indeed, Justice White stressed that BMI and ASCAP promoted the aims of copyright law through the "integration of sales, monitoring and enforcement against unauthorized copyright use." 69 NCAA's licensing agreements, by contrast, protected the proprietary interests of some football producers at the expense of others who were forced into the scheme. They had to be NCAA members to function in the market at all and, being in, were forbidden under threat of expulsion from marketing their product independently. Whereas the scheme in Broadcast Music enhanced the proprietary control of compos-

whether antitrust laws should be applicable to college sports, not to how the analysis ought to run once applied.

68. Hutchinson argues that the division of proceeds among the colleges concerns only "internal NCAA affairs," and that no court should "intervene solely to redistribute cartel profits more to the liking of the dominant members." Hutchinson, supra note 42, at 107, 109. Despite the manifest fact that no college could walk away from the NCAA and still produce and market college football, Hutchinson apparently thinks that the plaintiffs should have been denied standing to challenge these internal affairs. Id. at $107,109,111$.

69. 441 U.S. 1, 20 (1979). 
ers, the scheme in $N C A A$ coercively reduced colleges' control of their own games.

Although it does not address all of the open questions about the trade-off between market power and efficiency, $N C A A$ does answer important questions about the proper judicial response to the claim that defendants' concerted activities yield efficiencies. First, the court should consider whether the restraint would raise prices and lower output if defendants had market power. This is a theoretical question, and, at least at the facial stage, should be addressed as a structural issue. If defendants dominate a significant submarket-say, televised college football-the answer should be tentatively affirmative. ${ }^{70}$ Second, if the answer is yes, the court should next look critically at the efficiency claims. If the efficiencies are trivial, a charade, or unprovable, the inquiry should end. ${ }^{71}$ Defendants, having taken action that may raise prices and reduce output and that cannot yield provable offsetting advantages, are liable. Similarly, even if the claimed efficiencies are real and significant, if they can be substantially obtained by means significantly less threatening to competition, the inquiry should also end. This was the particular situation in $N C A A$, as it was in Maricopa. Third, if there is both a threat of cost enhancement and output reduction, and the promise of significant efficiencies not attainable by less restrictive means, the court should require a full-blown analysis of market power and the restraint's likely adverse effects, and of efficiency and the restraint's likely benefits. If that inquiry shows no market power, defendant wins. If it shows some power, but no (or only speculative or unprovable) efficiencies, plaintiff wins. This three-step analysis is strongly implied by $N C A A$, which also suggests that coercion is an independent wrong regardless of market power.

The question yet unanswered is: What results when defendant's arrangement yields both power and provable efficiency? An Aunerican court inight well opt for a European solution, ${ }^{72}$ holding that (1) if costs

70. Even a rigorous definition, such as one utilizing the methodology in Harris \& Jorde, supra note 25 , would probably indicate that a firm or cartel controlling the entire supply of televised college football would possess significant market power.

71. See the discussion in J.F. Brodley, supra note 46.

72. Article 85, paragraph 1, of the Treaty Establishing the European Economic Community forbids "agreements ... . which have as their object or effect the prevention, restriction or distortion of competition." V. KORAH, supra note 13, at 306. However, under paragraph 3, the Consumer Commission may declare the article inapplicable to such agreements when they yield efficiencies, do not impose restrictions unnecessary to attaining those efficiencies, do not eliminate competition as to a substantial part of the products in question, and provide "consumers a fair share of the resulting benefit." This provision reflects the goal of maintaining a market structure that will accommodate small firms. It also values long-run efficiency considerations more than short-run ones. Finally, the provision allows consideration of related financial and labor markets, as well as bankruptcy risks. In all of these respects, multivalued antitrust is the European approach. 
are reduced and prices are also reduced at least to some extent, so that consumers and producers share the gain in some credible proportion, the arrangement is legal; but (2) if the efficiencies are garnered almost entirely in monopoly profits, then the rule of reason is violated. After all, in the American antitrust tradition, unlike the Chicago tradition of welfare economics, it does matter whose bed is being feathered or whose ox is being gored.

This brings us to the assertion that $N C A A$ lacks an adequate theoretical framework. ${ }^{73}$ The source of this criticism, as with that focusing on $N C A A$ 's failure to require a market power analysis, is the Chicago conviction that a concerted arrangement should never be challenged unless it causes a significant "dead weight loss" in allocative efficiency. ${ }^{74}$ Neither coercion, nor denial of opportunity to a would-be entrant, nor (in the extreme Chicago view) even reduction of productive or dynamic efficiency, is of independent concern. Absent proof of bad allocative effects or of an explicit intent to achieve them, the only allowable assumption is that observed market conduct, whether individual or concerted, is aimed at product improvement or cost reduction. ${ }^{75}$

Efforts by Chicago theorists to ground this claim in legislative history have been almost embarrassing failures. ${ }^{76}$ Their fall-back position is a structural argument: allocative efficiency provides the magnetic north needed for successful navigation of the seas of competition policy; making it the sole goal of antitrust provides certainty and structure, and creates a greater expectation of agreement among expert evaluations than would be possible in a multivalued antitrust world. Implicit here is that this argument provides an objective reason for choosing Chicago's view. It does not. Once the choice is made that allocative efficiency is the only matter of social interest, that choice might be thought to yield a more

73. Hutchinson, supra note 42 , at 112 .

74. See, e.g., Easterbrook, supra note 3, at 1702-04.

75. See supra note 51 .

76. The best known Chicago effort is in R. BoRK, supra note 3, at 50. See also, Bork, Legislative Intent and the Policy of the Sherman Act, 9 J.L. \& EcoN. 7 (1966) [hereinafter Bork, Legislative Intent]. For a more recent Chicago effort to deal with legislative history, see Easterbrook, supra note 3. The essence of Bork's argument is that references to price gouging found in the legislative history of the Sherman Act should not be read as concerned with distributional effects, but should instead be interpreted as expressing concern about allocative efficiency. Bork contends that only by substituting this interpretation for the plain meaning of the legislature can the statute be made coherent. Bork, Legislative Intent, at 16-17. For one who sees himself as a strict constructionist in other contexts, this attitude seems to be a remarkable revision of the nation's economic "constitution." In any event, the Bork argument is wholly inconsistent with the serious historical scholarship on the Sherman Act, see H. Thorei.l., The FederAl Antitrust Pol.icy: Origin of AN AMERICAN Tradition (1954); Letwin, Congress and the Sherman Autitrust Law: 1887-1890, 23 U. CHI. L. REV. 221 (1956). For a recent and meticulous refutation of Bork's arguments, see L. KAPLOW, supra note 30, at 48-57; Lande, supra note 29. 
objective and technocratic way of doing antitrust analysis. ${ }^{77}$ But the choice itself is anything but objective; it has to win its place in the value arena it purports to have left behind. In that arena, it can make for itself only two significant claims. The first is that allocative efficiency is very important. The second, a pragmatic assertion, is that courts will be more comfortable if they choose a single value once and for all and then leave the matter to the experts.

If $N C A A$ is a blow to that radical conception of antitrust, it is to be celebrated rather than bemoaned. Of course efficiency is important, but it is not the only thing that is important. Antitrust has always responded to several related concerns: whether consumers are being exploited by excessive payments to producers (more than whether resource allocation is being distorted, though the two are linked); whether incentives for productive or dynamic efficiency are being reduced; whether competitors are being intimidated by predatory acts; whether entry is being stifled; whether particular market conduct is being concertedly or coercively required or forbidden. I see no credible reason to abandon these values, all manifest in the legislative history, all reflected in a century of case law, and, as $N C A A$ itself displays, all capable of being sensibly dealt with today.

The assertion that discernable structure and resulting analytical simplification would result from limiting analysis to allocative efficiency assumes too mucli about the precision and accuracy of the economist's analytical tools and about the breadtl of consensus among those wlio use them. It also assumes too little about the capacity of courts to weigh fairly all of the values Congress lad in view, while still making functional choices about whether undue injury to competition is present or imminent. Giving effect to the multiplicity of antitrust values Congress identified need not embroil a court in unmanageable social calculations. All the court need consider is whetlier or not the conduct under challenge injures competition as a process. Because protecting the competitive process is what antitrust is about, all of the other congressional goals are advanced by this focused inquiry. ${ }^{78}$

The excellence of Justice Stevens' $N C A A$ opinion is that it links cur-

77. Cf. B. Williams, Morality: AN Introduction to Ethics 31 (1972). In my own opinion it would not, at least if intent analysis were dispensed with, as most exponents of an "efficiency only" jurisprudence seem to favor. E.g., P. AREedA, supra note 22, at 11214(c); Green, supra note 52, at 34 (U.S. businesses laying off middle management to reduce costs); Areeda \& Turner, Predatory Pricing and Related Practices Under Section 2 of the Sherman Act, 88 HARV. L. REv. 697 (1975). As I have shown elsewhere, Sullivan, Monopolization: Corporate Strategy, the IBM Cases, and the Transformation of the Law, 60 TEx. L. REv. 587, 632-37 (1982), until very recently intent analysis was important, often dominant, in the sound disposition of antitrust cases. The problems intent analysis undoubtedly presents are, if anything, less serious ones for judicial evaluation than those difficulties associated with a theoretical analysis of effects.

78. See Fox, supra note 19; Pitofsky, The Political Content of Antitrust, 127 U. PA. L. REV. 
rent needs and purposes with legislative goals and long-established judicial technique. The proportionality that Justice Taft found in the common law and expressed in the search for less restrictive alternatives is again a guide to reasonableness. ${ }^{79}$ Together with the commitment to competition expressed in Professional Engineers, that proportionality provides structure enough for antitrust analysis.

$N C A A$, then, did not break new ideological ground. In terms of the central meaning of antitrust, it reaffirmed traditions long established, but newly under attack. What is distinctive in the opinion is its teaching that where competitive processes suffer blatant and significant injury-in this instance, by coercion-rule of reason analysis can be completed with dispatch. While Chicago critics may have raised some doubts for a time, it is now clear that NCAA is the rule, not the exception. FTC v. Indiana Federation of Dentists, ${ }^{80}$ the Court's most recent horizontal restraints case, reaffirms that violation of the rule of reason may be shown without any proof of market power. There, the Court unanimously ruled that, absent evidence of an offsetting procompetitive effect, proof that a group of dentists concertedly withheld a particular service from the market was sufficient to show a violation. ${ }^{81}$

I have devoted much of the discussion of these recent cases to refuting the Chicago claims that the Supreme Court reads the antitrust statute as do Judges Bork, Easterbrook, and Posner. Chicagoans can be forgiven for discovering their own predilections in the often confusing ink blots of judicial texts; the rest of us do that, too. But as Kaplow reminds us, the judicial debate is often better explained in terms quite distinct from our own preoccupations. ${ }^{82}$ These cases, for example, resonate far more with the long-standing debate about the relationship between rule and discretion than they do with the current academic debate about whether Chicago price theory or some variant of the structural approach makes the better starting point for antitrust analysis. The cases are quite catholic about the analytical tools they use. They focus more on whether the analysis should be categorical, yielding per se or presumptive rules for a wide range of situations, or case by case, bringing into consideration the specifics of each factual context and the proper level of generality at which to use the tools available.

At all events, the law seems not to need protection from the theo-

1051 (1979); Schwartz, "Justice" and Other Non-Economic Goals of Antitrust, 127 U. PA. L. REv. 1076 (1979).

79. See the Taft opinion in United States v. Addyston Pipe \& Steel Co., 85 F. 271 (6th Cir. 1898), modified and aff'd, 175 U.S. 211 (1899).

80. 106 S. Ct. 2009 (1986).

81. For a fuller discussion, see Fox, The Battle for the Soul of Antitrust, 75 CALIF. L. REV. 917, 920-22 (1987).

82. L. KAPLow, supra note 30 , at 1-4. 
rists, from Chicago or elsewhere. Because courts try to stay close to the facts, legal development tends to be incremental. In America's public life, unlike that of Europe, ideological obsessions have always been thought a peril. Courts, even in matters of Constitutional exegesis, have kept a distance from them. A theory does not become ideology until it is reified; nevertheless, courts tend to avoid strong commitments to particular theoretical approaches. They choose among theories fit for a task much as a craftsman might select a tool from a chest. In the process, the law is protected. As any given theory begins to fill the available space, diminishing returns set in. The law can stand only so much rigor, only so much cohesion. It has properties of its own that require it to remain open to case by case development in response to changing conditions.

\section{Concert Among Competitors: What is the Key?}

\section{Intra-enterprise Conspiracy}

A restraint must be planned or enacted in concert to violate section 1 of the Sherman Act. The question of when an agreement among affiliated entities will be characterized as a "contract combination or conspiracy" was addressed recently in Copperweld Corp. v. Independence Tube Corp. ${ }^{83}$ By a vote of five to three, the Court pruned away a thicket of earlier intra-enterprise conspiracy cases $^{84}$ to hold that concerted action by a corporation and its wholly owned subsidiary was per se lawful under section 1 regardless of whether it hurt other firms and restrained market competition. ${ }^{85}$ The Court rejected the view, articulated in Stevens's dissent, that an intra-enterprise conspiracy doctrine based on a rule of reason analysis should be used in part to correct the Sherman Act's failure to forbid even blatantly anti-competitive single firm conduct that does not dangerously threaten monopoly. (Because of this failure, conduct like that in Copperweld can be challenged only under section 2.) In addition, though this is less clear, the Copperweld majority seems to have set the stage for a new approach to agreements among affiliates that are less than wholly owned. Hereafter, decisions about whether affiliates can conspire will likely turn on the distinction between common and separate control. $^{86}$

Copperweld cannot be read as limiting antitrust analysis to deter-

83. 467 U.S. 752 (1984).

84. Perma Life Mufflers, Inc. v. International Parts Corp., 392 U.S. 134 (1968); Timken Roller Bearing Co. v. United States, 341 U.S. 593 (1951); Kiefer-Stewart Co. v. Joseph E. Seagram \& Sons, Inc., 340 U.S. 211 (1951); United States v. Yellow Cab Co., 332 U.S. 218 (1947).

85. Copperweld, 467 U.S. at 777.

86. Unless the line drawn in Copperweld is taken as a technical and limited per se rule, the opinion's emphasis on unification through ownership will require, in situations of less than full ownership, a functionally significant surrogate through which to evaluate the extent of unification. A control test seems the most likely response. See Copperweld, 467 U.S. at 771-74. 
mining whether output is restricted or as implicitly rejecting analyses that take account of other values. ${ }^{87}$ Such a reading would be remarkably strained. For one thing, the majority's insistence on separate decisionmakers as a prerequisite for a conspiracy tells us nothing about the substantive effects that must be established for a conspiracy to run afoul of the law. Presumably that issue will be decided with imploded per se/ rule of reason analysis. For another thing, the issue that separated the majority and Justice Stevens does not turn on whether output restriction is the sole evil. Just as one could have accepted the Stevens view even if convinced by Chicago ideology, one can accept the majority result even if convinced that the aim of antitrust is to protect competition as a process in order to advance a variety of social values. The majority opinion chose greater simplicity in antitrust analysis at the cost of greater comprehension. Interestingly enough, the exponent of comprehension was Justice Stevens who, on rule of reason issues, has tended to champion a fine compromise between predictability and economy of judicial effort on the one hand, and precision of results on the other.

\section{Evidence Sufficient to Prove Conspiracy}

How do unaffiliated competitors cooperate and what evidence is sufficient to prove such cooperation? These are serious questions, and the second is one that current law does not handle very well. The Supreme Court has said little of significance about conspiracy evidence since Interstate Circuit, Inc. v. United States, ${ }^{88}$ Theatre Enterprises, Inc. v. Paramount Film Distributing Corp., ${ }^{89}$ and FTC v. Cement Institute. ${ }^{90}$ The imprecision of the norms derivable from those cases leaves immense

87. Some commentators are given to collecting cases assertedly consistent with the "efficiency is the only value" ideology. E.g., Gerhart, The Supreme Court and Antitrust Analysis: The (Near) Triumph of the Chicago School, 1982 SuP. CT. REv. 319; Markovits, The Burger Court, Antitrust, and Economic Analysis, in The Burger Court 180-91 (V. Blasi ed. 1983); Posner, The Chicago School of Antitrust Analysis, 127 U. PA. L. REV. 925 (1979). Among the cases always or often cited are Jefferson Parish Hosp. Dist. No. 2 v. Hyde, 466 U.S. 2 (1984), Reiter v. Sonotone Corp., 442 U.S. 330 (1979), National Soc'y of Professional Eng'rs v. United States, 435 U.S. 679 (1979), and Continental T.V. Inc. v. GTE Sylvania, Inc., 433 U.S. 36 (1977).

In cases involving vertical restraints, the Court has recently shown a more explicit concern about efficiency. It has also suggested the possibility for somewhat more sophisticated analysis, at least to the extent of recognizing "free rider" problems. But no recent case, including the line of cases culminating in NCAA and Indiana Federation of Dentists, suggests that efficiency is now the only goal. For a thorough discussion refuting excessive claims (and concerns) about the efficiency orientation of recent case law, see L. KAPLow, supra note 30, at 35-62.

88. 306 U.S. 208 (1939) (finding of conspiracy warranted where movie distributors received a proposal for joint action from their exhibitor, tendered identical counteroffers, undertook pricing that would benefit each only if all participated, and failed to offer rebuttal evidence from available source).

89. 346 U.S. 537 (1954) (proof of parallel business behavior by movie distributors in restricting "first runs" was by itself insufficient to constitute an offense where defendants displayed little interdependence and introduced explanatory evidence of individual business judgment). 
discretion with the finder of fact. Consequently, the judge (or jury) is free, perhaps even obliged, to intrude her (or its) own values into the decisionmaking process. If a particular judge thinks, for example, that concerted price setting is nasty conduct, all she need do is predicate her findings of conspiracy on minimal evidence of collusion. If, by contrast, a different judge regards the antitrust laws as institutionalized paranoia-an undue intrusion on honest business and busy courts-he will refuse to infer conspiracy and instead require compelling proof. We are, in this respect, heirs to a legal system that leaves a remarkable amount of this central issue of antitrust adjudication open to discretionary norm selection.

How ought questions of conspiracy be addressed? Competitive strategy in general-concerted activity as well as single firm conducthas grown increasingly sophisticated. ${ }^{91}$ It has also become subject to legal screening, often internal, and the pressures may be strong to change style rather than conduct in attempting to avoid violating the antitrust laws.

Consider the following example. The evidence in United States $v$. American Airlines ${ }^{92}$ entailed an explicit telephone proposal by Crandall of American to Putnam of Braniff that the two airlines increase their prices, a proposal that Putnam (after discussion with counsel) decided not to accept. Now, suppose Crandall liad been more subtle. Suppose he had talked to his lawyer before making the overture. Might the exhortation to Putnam not then have taken a different form? Crandall might have called in the business press. He might have said in an interview the substance of everything he actually said in the phone call. Putnam, after reading the interview, might also have discussed it with his lawyer. Knowing that American would follow, he might have decided that the economic advantages of increasing Braniff prices outweighed the legal risk of violating section 1 .

One can argue against treating agreements negotiated through sucli sanitized means as violations of the Sherman Act. But if price enhancement and output reduction present serious social concerns, intent to achieve these by conspiracy, no matter how sanitized, should be forbidden. On the facts I have supposed, a jury ought to be instructed that if Crandall gave his interview witl the intent of inducing Braniff to increase

90. 333 U.S. 683 (1948) (evidence of cement producers' interdependent cooperative conduct in following a basing-point system of pricing supported a finding of a section 1 violation).

91. See generally M. Porter, Competitive Advantage (1985); M. Porter, Competrtive STRATEGY (1980). Economic and antitrust literature appraising various strategies from the public interest perspective is now expansive. An important recent paper setting forth an extensive bibliography is $O$. Williamson, Delimiting Antitrust (unpublished paper delivered at the Airlie House Conference, The Antitrust Alternative, March 28, 1987).

92. 743 F.2d 1114 (5th Cir. 1984). 
its price, and if Braniff responded in reliance on that commitment, both airlines violated the law.

Concerted conduct that raises prices and reduces output is, after all, the only conduct about which there is broad negative consensus; everyone agrees that it hurts competition. At least this kind of conspiracy ought to be subject to demanding norms. As a practical matter, a court can treat the conspiracy issue in a price-fixing case somewhat more aggressively than it can in an attenuated rule of reason claim. But it would be a tragedy if Matsushita Electrical Industrial Co. v. Zenith Radio Corp..$^{93}$ accelerated the tendency toward resolving conspiracy issues summarily on the ground that the market involved was contestable, especially in situations like the hypothetical. ${ }^{94}$ If antitrust is to serve the nation well as it moves into the 1990's, it must make a forceful commitment to at least the rudimentary idea that competitors ought not to fix prices.

\section{Interdependent Coordination}

So much for the cartel, subtly achieved. If you believe, as I do, that purely interdependent cooperative conduct also occurs in oligopolistic markets, ${ }^{95}$ the question remains whether antitrust can respond usefully. On this point, I think Turner ${ }^{96}$ had the better of the 1960 's debate with

93. $106 \mathrm{~S}$. Ct. 1348 (1986) (granting summary judgment to Japanese electronics manufacturers in an action by American television manufacturers alleging the fixing of high sales prices in Japan to fund a low export price conspiracy).

94. City-pair air transport markets like those involved in American Airlines are contestable markets in their quintessence. Bailey \& Baumol, Deregulation and the Theory of Contestable Markets, 1 YALE J. ON REG. 111 (1984). Suppose Matsushita were construed to mean what it could be literally taken to mean-that a defendant's summary judgment is warranted, despite inferential evidence of conspiracy, whenever the allegation of conspiracy seems implausible on grounds of deductive microtheory. On that assumption (given that price fixing between two firms in a contestable market is theoretically implausible), even a consummated price-fixing conspiracy between American and Braniff would have been provable only by direct evidence. But direct evidence only was available to prove the case against American because Braniff rejected American's invitation to conspire. Such a view of summary judgment's scope in conspiracy cases would greatly diminish the value of section 1. It would also run counter to recent scholarship about what actually happens to prices when a single airline dominates a theoretically contestable city-pair market. Call \& Keeler, Airline Deregulation. Fares, and Market Behavior: Somc Empirical Evidence, in ANalytical Studies IN TRanSPORT Economics 221 (A. Daughety ed. 1985).

95. See F. Scherer, Industrial Market Structure and Economic Performance $497-$ 525 (2d ed. 1980); W. SHEPHERD, THE ECONOMICS OF INDUSTRIAL ORGANIZATION (1979). The seminal work on performance in oligopolistic markets was E. CHAMBERL.iN, THE THEORY or Monopolistic Competition 46-51 (7th ed. 1956). See also J. BAin, Industrial Organization 302-71 (2d ed. 1968). Bain's cross-sectional analysis pointed the way to guidelines and screens based on concentration ratios.

96. See Turner, The Scope of Antitrust and Other Economic Regulatory Policies, 82 HARV. L. REv. 1207 (1969); Turner, The Definition of Agreement Under the Sherman Act: Conscions Parallelism and Refusals to Deal, 75 HARV. L. REV. 655 (1962). Turner argued that section 1 is doctrinally inappropriate for regulation of oligopolistic behavior because, in certain markets, interdependent pricing is more an inherent feature than a collusive agreement. Moreover, he argued, 
Posner, ${ }^{97}$ and nothing since has altered my conclusion. Even though interdependent actors may be construed to constitute a "combination" covered by section 1 , that section is inadequate to deal with purely interdependent pricing because fashioning a remedy is so difficult. But the section can be applied to interdependent conduct that hurts competition in ways that can be rectified by a conduct remedy. ${ }^{98}$ If courts persist in holding otherwise, corrective legislation would be appropriate.

The ultimate problem, however, is not that cooperative pricing escapes the antitrust net. Rather, it is that leading firms in tight oligopolies can for long periods convert monopoly returns into wasteful excess capacity, factors, and other $x$-inefficiencies. They can do so without either overt or covert cooperation, but simply through satisficing and imitative behavior. ${ }^{99}$ This problem cannot be reached through either section 1 or joint monopolization theories; even construing Interstate Circuit, Inc. v. United States ${ }^{100}$ most liberally, these theories work only when defendants are following common competitive strategies tending either to insulate them from competition or to lever their power into new markets. But in some tightly concentrated markets, there is neither agreement nor a facilitating device, but merely the pattern of the nonaggressive, often wasteful performance frequently associated with tight oligopoly. ${ }^{101}$ Unless the nation is ready for deconcentration legislationand I see no indication that it is-there is no plausible antitrust response to this jointly enjoyed quiet life, save to police against further concentration through mergers and to hope that technological development or new

the section 1 injunction remedy is economically untenable in such cases because it would require the firms to ignore competitors' pricing behavior and would mire the courts in rate regulation.

97. See Posner, Oligopoly and the Antitrust Laws: A Suggested Approach, 21 Stan. L. Rev. 1562 (1969). Posner contended that section 1 is an adequate check on oligopolies. He argued that oligopoly is a necessary but not a sufficient feature of price fixing; firms must choose to further anticompetitive, interdependent conduct. Therefore, he reasoned, wherever noncompetitive pricing is proved, a trier of fact can find tacit collusion and a section 1 violation.

98. In Boise Cascade Corp. v. FTC, 637 F.2d 573 (9th Cir. 1980), for example, the court refused to enforce an FTC cease and desist order against parallel use of a delivered-pricing system. Nonetheless, interdependent use of a particular pricing system could, without strain on statutory language or purpose, be held within the reach of section 1 as well as section 5 of the FTC Act, for such conduct creates a "combination." Given that such conduct, unlike that of firms merely following a price leader, can be remedied by injunction, there is no policy reason for not so holding. Moreover, the Boise Cascade result seems inconsistent with FTC v. Cement Institute, 333 U.S. 683 (1948), and Triangle Conduit \& Cable Co. v. FTC, 168 F.2d 175 (7th Cir. 1948) (enforcing a Commission cease \& desist order against steel conduit manufacturers who collectively defined and monitored a basing-point system of pricing), aff'd by an equally divided Court sub nom. Clayton Mark \& Co. v. FTC, 336 U.S. 956 (1949). Compare Bogosian v. Gulf Oil Corp., 561 F.2d 434 (3d Cir. 1977), cert. denied, 434 U.S. 1086 (1978), which may go so far as to countenance the inference of conspiracy from nothing more than parallel price moves.

99. See Harris \& Sullivan, supra note 26 , at 915-23.

100. 306 U.S. 208 (1939).

101. See Harris \& Sullivan, supra note 26 , at $915-23$. 
foreign entry will shake up existing, quiescent American oligopolies. ${ }^{102}$

\section{II}

\section{MAINTAINING COMPETITION: 1990 AND BEYOND}

I have thus far outlined where the law is today. To test whether it will provide guidance for dealing with the emerging problems of the changing economy, I will identify some of the current influences on markets of American firms, speculate about some of the incentives for cooperation that they create, fashion a few hypotheticals that stand near the edges of current law, and discuss how such problems might be addressed.

\section{A. The Scope and Significance of Recent Structural Changes}

A firm with market power need not minimize cost. Revenues that would otherwise go to stockholders as monopoly rents may instead be spent to preserve power, to overcompensate management, or to enhance firm (and hence management) prestige and amenity. In American industries that are both concentrated and unionized, firms pay part of their monopoly rents to labor, both in the form of excessive wage rates and in work rules that protect jobs at the expense of excess production costs. ${ }^{103}$ Firms in concentrated markets are also more likely than others to invest in overcapacity, which both eases responses to demand swings and deters entry. ${ }^{104}$ Finally, firms with market power often develop rules of thumb for allocating purchase orders, use inadequate quality control procedures, indulge in excessive staffing, and display other $x$-inefficiencies. ${ }^{105}$

From World War II until the 1970's, many American firms could afford these indulgences. Some were in regulated industries, others in industries long concentrated. Patterns of rivalry were focused on aspects of differentiation more apparent in advertisements than in use, and more effective in discouraging entry than in altering market shares. ${ }^{106}$ So long

102. Issues about the most suitable market structure and about the appropriate absolute size of firms are on the agenda of European policy makers. Even though many European economists believe that major European firms are already achieving available scale economies, a view often heard in Brussels is that European firms should be encouraged to grow or merge to achieve sizes comparable to those of the American firms engaging in European markets. Given the increasing internationalization of markets, it may well be time for further international discussion of competition policy, perhaps focusing on mergers and joint ventures. The vehicle might be OECD, the United Nations (with focus on the Restrictive Business Practice Code), or, perhaps ideally, a well devised ad hoc group.

103. Salinger, supra note 52, at 167-69.

104. R. HALL, supra note 52.

105. See T. PETERS \& R. WATERMAN, supra note 52; Hampton \& Cook, supra note 52; Green, supra note 52; U.S. Auto Makers Reshape for World Competition, supra note 52.

106. Concerning conditions of rivalry in oligopolistic markets, see the authorities cited snpra in note 95. Concerning product differentiation and advertising in particular, see W. COMANOR \& $T$. Wilson, AdVERTISING AND MARKet Power (1974); Schmalensee, Entry Deterrence in the Readyto-Eat Breakfast Cereal Industry, 9 BELL J. ECON. 305 (1978). 
as these firms maintained the expected profit levels, stockholders were unlikely to complain that monopoly returns, properly theirs, were being paid out in unnecessary costs.

It did not last, however. Deregulation caught up with some of the noncompetitive industries, particularly the airline industry. ${ }^{107}$ Others encountered new competition as a result of new technology. ${ }^{108}$ Still others found their power eroded by a series of changes that extended markets from national to international dimensions. ${ }^{109} \mathrm{By}$ the early 1970's, foreign industries had overcome not only war devastation, but also the technological lag associated with it. GATT, the IMF, and other institutions designed to reduce trade barriers and increase economic interdependence worked remarkably well. ${ }^{110}$ Transportation technology vastly improved. ${ }^{111}$ In some industries, especially the automobile industry, even the OPEC cartel helped eliminate barriers to foreign entry. ${ }^{112}$ In the 1980's, the Reagan macropolicy also made foreign goods relatively cheap to American consumers.

For almost two decades now, foreign competition has battered away at American positions of power in automobiles, steel, electronics, and other important industries. ${ }^{113}$ As a consequence, American firms in industries facing new competition are making heroic efforts to reduce excessive wage rates and to alter inefficient work rules. ${ }^{14}$ Inefficient purchasing practices are being abandoned. Staffs are being cut. Instead of enjoying the quiet life, American firms are growing leaner and more competitive-or they are dramatically contracting. Otherwise, they would fail to survive.

By and large, these changes have been good for American consumers. As markets have expanded, power has eroded, options have widened, product development has been less superficial, quality has improved, and prices have fallen or been contained. But many American firms and American work forces have suffered, sometimes severely. They

107. See Airline Deregulation Act of 1978, Pub. L. No. 95-504, 92 Stat. 1705 (1978) (codified as amended at 49 U.S.C. $\S 334$ (1982)).

108. As to the complex effects of innovation on market competition, see R. NELSON \& S. WINTER, AN EVOlutionary THEORY OF ECONOMIC CHANGE 195-354 (1982).

109. See Harris \& Jorde, supra note 25, at 62-63; Landes \& Posner, Market Power in Antitrust Cases, 94 HaRv. L. REv. 937, 966 (1981).

110. Jackson, Import Practices: Are They Rcally Unfair?, L. QUadRangle Notes, Winter 1986, at 26, 27.

111. The container ship and related road-rail developments greatly reduced per unit transportation costs.

112. See Sullivan, Preserving Efficiency and Assuring Corporate Accountability, 94 Conf. BOARD INFO. BULL. 6 (1981).

113. Id.

114. Efforts at wage reduction in the newly deregulated airline industry as well as efforts to reduce labor costs in the steel and automobile industries by wage freezes, more efficient use of labor, development of off-shore production, and other devices are all notorious. 
have also reacted. Their strategies have included acting concertedly through joint ventures or loose-knit arrangements. ${ }^{115}$ Nor are these responses limited to American cooperation. Foreign firms can also proceed cooperatively, sometimes under the aegis of foreign governments, in markets where American firms compete. ${ }^{116}$ How should American antitrust respond to such developments?

\section{B. Some Thoughts About Analytical Methodology}

When competitors cooperate, the arrangement they fashion, whether regarded as contract making or institution building, must be analyzed superficially (as with a facial inquiry used to apply per se norms), more fully (as under a truncated rule of reason), or thoroughly (as under the full-blown rule of reason). Whatever the mode, the analysis inquires into the purpose and effect of the arrangement. As to harm, the analysis asks whether market power is being obtained, protected, extended, or inappropriately exercised. As to benefits, it may identify efficiencies, market making, or market failure correction.

One can generalize about how the harms might be achieved. ${ }^{117}$ There are only a few ways that a firm can obtain or enhance its powerby increasing concentration; by creating entry barriers; or by acting strategically either to discourage entry or expansion, to raise rivals' costs, or to inhibit undesired conduct by rivals. There is only one way a firm can extend its power into other markets-by leverage, whether statically or dynamically understood. There are various ways a firm can exercise its power-by monopoly pricing, limit pricing, price discrimination, barrier building, and wasteful spending.

One can also generalize about benefits, especially efficiencies, though it is harder. Productive efficiencies can result from scale economies, longer production runs, learning or experience benefits, or better (or more widely deployed) information. Productive and allocative efficiencies can result from internalization of costs or benefits to sharpen incentives, or from reduction of other market failures. This catalog is not exhaustive, but it exemplifies relevant factors.

A situation calling for per se analysis virtually identifies itself. Its hallmarks are manifest price enhancement, output restriction, or coercive restraint of rivals. Of greater interest are the choices courts make among possible procedures when further analysis is needed. Such choices

115. See, e.g., General Motors Corp., 103 F.T.C. 374 (1984) (GM and Toyota permitted under FTC consent decree to form a joint venture to manufacture and sell to U.S. and Canadian markets up to 250,000 cars per year for a period of 12 years).

116. See, e.g., Matsushita Elec. Indus. Co. v. Zenith Radio Corp., 106 S. Ct. 1348 (1986).

117. The following discussion draws upon the useful taxonomy in Williamson, Assessing Contact, 1 J.L. ECON. \& ORGanization 177 (1985). 
involve economic thinking, and there are several possible approaches. Practical good sense may be enough-the kind of thinking that one might intuitively use, for example, in identifying manifest price effects ${ }^{118}$ or in discriminating between otherwise similar situations on the basis of the presence or absence of coercion. ${ }^{119}$ Economic thinking may involve theoretical perspectives, too. I stress the plural because economic theory is many things: a laboratory where new approaches are tested; ${ }^{120}$ an arena where adherents of competing schools form teams and joust each other; ${ }^{121}$ a political convention where ideologies conflict. ${ }^{122}$ In evaluating both harms and benefits, the lawyer or judge doing antitrust analysis must engage in simple economic reasoning and should be open even to quite sophisticated expressions of that art. This does not mean she should commit herself or the law to a single perspective. It means, rather, that she must choose from among the alternatives a perspective appropriate to the inquiry at hand and supportive of the values that the judge concludes the antitrust laws are intended to protect.

The task of the law and the role of lawyers in choosing, in particular instances, among possible theoretical approaches is neither minor nor passive. It demands practical wisdom and a critical sensibility, as well as an active sense of craft. In the first place, any analysis presupposes an underlying prior synthesis. ${ }^{123}$ In antitrust, that underlying synthesis is not, as some seem to suppose, one of the current governing paradigms of economic theory. ${ }^{124}$ To the contrary, the underlying synthesis is the received law-including, of course, those elements of economic theory,

118. Examples of such common sense are the decisions in United States v. Trenton Potteries Co., 273 U.S. 392, 396-98 (1927) (noting that agreements that set or maintain prices are not considered reasonable restraints simply because the prices are reasonable), and in United States $v$. Socony-Vacuum Oil Co., 310 U.S. 150, 222 (1940) (prices need not be "uniform and inflexible" to violate the Sherman Act). In these and other cases, courts have engaged not in theoretical model building, but in economic thinking of a practical variety. Yet, no one seriously questions that they reached the right results.

119. NCAA v. Board of Regents, 468 U.S. 85 (1984), is the most recent example.

120. Economics in its highest form entails serious, careful, and rigorous efforts to improve existing models. These are then introduced into the literature, where they are exposed to critical commentary and reaction. A notable recent example is R. NELSON \& S. WINTER, supra note 108. Williamson's best work has similar characteristics. See Williamson, The Vertical Integration of Production: Market Failure Considerations, 61 AM. EcoN. Rev. 112 (1971).

121. See, e.g., Posner, supra note 87 (contrasting the Chicago and Harvard schools of antitrust analysis).

122. See the discussion in Harris \& Sullivan, supra note 26.

123. This, I believe, is an epistemological imperative; one can not take something apart that is not, in some sense, together when the analytical process begins.

124. This particular misapprehension is found among commentators with quite different theoretical perspectives and ideological commitments. E.g. Posner, supra note 87; Williamson, Antitrust Enforcement: Where It Has Been; Where It Is Going, in INDUSTR1Al ORGanization, ANTitrust, AND Public Policy 41 (J. Craven ed. 1983). 
like market definition, which already have been institutionalized as part of the law.

In the second place, it is the lawyer, then the judge, who must ultimately do the law's analytical work. This work requires awareness of the law's multivalued commitments and its need to simplify in the interest of administrability, to generalize and to move along established paths. Both the lawyer and the judge must shop for economic theories; they must proceed much as they might in another context-a tort case, for example, where they might shop for theories about metal fatigue.

In selecting a theory, the lawyer has a large menu. Price theory ${ }^{125}$ and structural analysis ${ }^{126}$ are most useful in evaluating power. The perspective of the price theorist dominates thinking about price fixing, the classic per se offense. When fuller analysis is needed, structural analysis can be brought to bear, with its focus on market definition, concentration ratios, and entry barriers. While all this is familiar, some situations may require the lawyer to look to approaches drawn from transaction costs economics, ${ }^{127}$ the strategic literature, ${ }^{128}$ and even evolutionary economics. ${ }^{129}$ Leverage theory is also available, at least in static form; both the Court $^{130}$ and Congress ${ }^{131}$ have employed it. Additionally, new insights emerge, such as that developed by Kaplow and others, who have insightfully linked the leverage concept to strategic motivations. ${ }^{132}$

125. E.g. T. Calvani \& J. Siegfried, Economic ANalysis and ANTITRUST LaW (1979); G. STIGLER, THE ORGANIZATION OF INDUSTRY (1968).

126. W. AdAMS, The STRUCtURE OF AMERICAN INDUSTRY (7th ed. 1986); F. SCHERER, supra note 95 .

127. The primary contributor to the field of transaction-cost economics has been Williamson. See, e.g., O. Williamson, Markets and Hierarchies: ANalysis and ANTITrust IMpliCATIONS (1975).

128. See, e.g., Ordover \& Willig, An Economic Definition of Predatory Product Itunovation, in id. at 301; Porter, Strategic Interaction: Some Lessons from Industry Histories for Theory and Antitrust Policy, in id. at 449; Spence, Competition, Entry, and Antitrust Policy, STRATEGy PREDATION AND ANTITRUst ANAlysis 45 (S. Salop ed. 1981); see also Spence, Contestable Markets and the Theory of Industry Structure: A Review Article, 21 J. EcoN. LIT. 981 (1983). For recent contributions, see Krattenmaker \& Salop, Anticompetitive Exclusion: Raising Rivals' Costs to Aclieve Power Over Price, 96 YALE L.J. 209 (1986) and O.E. Williamson, supra note 91.

129. See, e.g., R. NELSON \& S. WiNTER, supra note 108.

130. See, e.g., Jefferson Parish Hosp. Dist. No. 2 v. Hyde, 466 U.S. 2, 9-18 (1984).

131. See, e.g., Clayton Act $\$ 3,15$ U.S.C. $\$ 14$ (1982).

132. See Kaplow, Extension of Monopoly Power Through Leverage, 85 CoLUM. L. REV. 515, 547-52 (1985); M. Roe, Monopoly Power and Leverage: The Double Count Argument (March 18, 1986) (unpublished manuscript on file with the author). Bork and other Chicagoans have challenged static leverage theory with the so-called "double count" argument. They assert that for a monopolist to oblige purchasers to prefer it in another market iu which it lacks power, the monopolist (unless the levered transaction yields efficiency) must give up an amount of its return in the monopolized market equivalent to the advantage it exacts in the second market. Dynamic leverage analysis refutes this argument. In a world of bounded rationality, buyers may lack the information needed to exact an offset in the monopolized market, or may use discount rates on future costs different from the monopolist's. The buyers may be largely indifferent to the monopoly overcharge because each knows that all its competitors must also pay it and that ail can pass it on. Finally, any one of the 
Issues concerning the use of market power call for an evaluation not of structure, but of performance. In the field of industrial organization economics, Bain emphasized the possibility of cross-sectional analysis of structure-developing general norms that identify the risk of power when compared to simple structural data. ${ }^{133}$ Mason, by contrast, invited a deeper analysis of the interactions that become institutionalized within a single industry. ${ }^{134}$ Any examination of pricing (monopoly, limit, or discriminatory), rent chasing (spending to protect power), or $x$-inefficiencies (spending wastefully) is likely to be in the Mason tradition.

Efficiency issues require an eclectic approach. Their presence may be confirmed or refuted by engineering evidence, by conventional price theory, by strategic analysis, by transaction costs, or by evolutionary economics. Particularly interesting is whether cooperative action to mitigate a market failure can be considered to promote competition. There are, of course, many possible market failures. ${ }^{135}$ Rationality is bounded and information is often costly, asymmetrically distributed, inaccurate, or simply unavailable. ${ }^{136}$ There can be negative or positive externalities. There can be excessive focus on the short-run maldistribution of resources, as well as numerous other short-run failures. As the nation relies less and less on regulatory responses to such problems, perhaps courts will fine tune antitrust analysis to encourage, or at least permit, well-conceived cooperative efforts by market actors designed to improve the way markets work.

In all these areas of competitive harms and competitive benefits, a judge, having determined what economic goals are reflected in the statute and the case law, must select manageable ways to mediate between those goals and the evidence before him. He should begin with practical thinking, then start down the paths of familiar theory already institutionalized

buyers may fear being disadvantaged if it declines to pay the (levered) terms because, unless all other buyers (or enough of them to make the seller act differently) also decline, the seller might cut the recalcitrant buyer out of the monopolized market. This refutation of Bork's double count argument is also reflected in Krattenmaker \& Salop, supra note 128.

133. See J. BAIN, supra note 95 , at $377-496$. Guidelines and structural prescreening before predation analysis are examples of more recent applications of such structural analysis. See, e.g., Department of Justice Antitrust Division Merger Guidelines, 47 Fed. Reg. 28,493 (1982); Horizontal Merger Guidelines of the National Association of Attorneys General, supra note 25; Joskow \& Klevorick, A Framework for Analyzing Predatory Pricing Policy, 89 Y ALE L.J. 213 (1979).

134. E. Mason, Economic Concentration and the Monopoly Problem (1957). Brief, readable, current treatments of several important industries appear in W. ADAMS, supra note 126.

135. See, e.g., Harris \& Carman, Public Regulation of Marketing Activity: Part I: Institutional Typologies of Market Failure, J. MACromarketing, Spring 1983, at 49, 53 (discussing eight types of market failure: imperfect competition, excessive competition, anticompetitive conduct, imperfect information, side effects, public goods, merit goods, and income maldistribution).

136. The seminal work on bounded rationality and satisficing behavior is Simon, $A$ Behavioral Model of Rational Choice, 69 Q. J. ECON. 99 (1955). A more recent article reviewing much of the literature on bounded rationality is Simon, Rational Decision Making in Business Organizations, 69 AM. ECON. REV. 493 (1979). 
in the law, ${ }^{137}$ and, finally, stand ready to assess with tolerant criticism the potential greater understanding that newer theory provides. ${ }^{138}$ In the subsections that follow, I will explore some situations in which antitrust values and analytical techniques interact.

\section{Cooperative Responses By American Firms to Foreign Competition}

Let me first consider a hypothetical concerted response by American firms to market changes resulting from foreign competition. Assume that due to bounded rationality, interdependence, and satisficing behavior, American firms have long viewed each other across a conventional market boundary that is technologically arbitrary. (Consider, for example, the traditional boundary between IBM in computers and AT\&T in telephone equipment and service.) Suddenly, however, competition emerges from Europe or Japan. The foreign entrants do not draw the same market boundaries or act on the same interdependent compact that has prevailed here. They make integrative offerings to American buyers; offerings that no one firm on either side of the traditional American line can immediately match. In response, two American firms, each dominant in its own field, form a joint venture for a specified period of years. They agree to share relevant technology, conduct joint research, and jointly develop and sell the hardware and software needed to meet, and hopefully beat, offerings from abroad. Is this behavior lawful?

\section{Preliminary Structural Screen}

To answer the question posed, we must begin by aggregating the output of all firms in the related American markets, including foreign firms now making or planning to make sales efforts here. One should use a conservative market definition-one that follows the Jorde-Harris approach, ${ }^{139}$ but can be constructed from readily available data. At this stage, one should also resolve doubts in ways that narrow the market. Next, we must calculate the venturers' shares of the market so defined. If their shares are not great enough to suggest a risk of power-i.e., such that a merger between them would offend the 1968 Merger Guide-

137. Price theory and structural analysis are both basic tools. Price theory models are often overemployed and must be used with caution. For a review of some of the problems, see Hovenkamp, supra note 30. Structural theory is most useful in gauging power, and as a screen for identifying off-trail strategies that may require closer analysis. See Joskow \& Klevorick, supra note 133.

138. Marris \& Mueller, The Corporation. Competition, and the Invisible Hand, 18 J. EcoN. LiT. 32 (1980), contains a useful review of recent literature on competition and market performance. For additional literature on economic theories, see authorities cited supra in notes $52,128,132,136$.

139. Jorde and Harris propose an antitrust market definition that (1) focuses on the interests protected by the pertinent statute; (2) takes account of economic realities; and (3) explicitly shifts burdens to gain required information from the litigants. Harris \& Jorde, supra note 25 , at 6. 
lines ${ }^{140}$-the inquiry should end.

Such a conservative preliminary analysis is plainly justified by recent developments. This structural screen serves to confine inquiry within narrow bounds without creating undue risk of error. If, however, venturers' market share exceeds acceptable limits (as my hypothetical suggests), the inquiry must widen. The three elements of the venture must then be analyzed separately.

\section{Sharing Existing Technology}

What if these firms did nothing but share existing proprietary technology so that each could compete more effectively with the new foreign entrants? Would this be a violation? Ignoring outsiders for a moment, such sharing trades an enhanced competitive position for each firm in the other's applications market (or in the new wider applications market) for the foregone opportunity for each to enter that market on its own. This result alone would be a procompetitive trade-off, almost regardless of market shares. But the sharing might also impact other competitors in the applications market through a patent pool effect. ${ }^{141}$ Each venturer wants to cross the market line breached by foreign entry, and without the venture, one or both of the firms might have crossed the line by exchanging technology licenses with smaller firms. Such an outcome might cause fewer competition problems in the applications market and might result in a wider, more rapid deployment of the technology in America, at a price approximating that which would result from competitive licensing. ${ }^{142}$

I have lately observed among antitrust advisers a tendency to favor joint ventures over business structures with somewhat different managerial characteristics. Thus, a lawyer today might propose a joint venture as a substitute for a patent exchange in order to reduce antitrust risks. As a practical matter, I do not counsel against such cosmetic changes. Yet, I do suggest that enforcement agencies, potential plaintiffs, and courts ought to analyze the purposes and effects of a concerted arrangement, not merely its label. For example, however we should treat an arrangement like that found in Standard Oil Co. v. United States, ${ }^{143}$ its

140. U.S. DEP'T OF JUSTICE, 1968 MERGER GUIDELINES (May 30, 1968), reprinted in 2 Trade Reg. Rep. (CCH) $\Uparrow 4510$ (Aug. 9, 1982).

141. Patent pooling is an arrangement in which manufacturers agree to exchange patent licenses among themselves.

142. Cf. Standard Oil Co. v. United States, 283 U.S. 163, 171, (1931) (exchanging patent rights does not violate Sherman Act if all manufacturers wishing to participate may enter the market on reasonable terms).

143. Id. at $\mathbf{1 6 7 - 6 8}$ (corporations owning patents for "cracking" processes that greatly increased the gasoline yield from crude petroleum exchanged patent rights and shared royalties). 
validity should not turn on whether the arrangement is called a joint venture rather than a patent pool.

If sharing technology gives participants a big advantage over nonparticipants, it may unduly disadvantage the latter in applications markets as well. ${ }^{144}$ This "essential facilities" issue, which focuses on fairness and market access as well as on consumer welfare, calls for a simplified structural analysis. Presumably, however, this issue would not arise until excluded competitors expressed their grievances, or the two participants, acting concertedly, appeared capable of dominating the market. ${ }^{145}$

Other issues arise from the international character of this hypothetical market. One is whether smaller American competitors who have previously respected the conventional market boundary should be given access to the venture if a number of foreign firms are positioned to compete with the venturers. Given adequate foreign competition, a consumer-centered antitrust policy would answer this question negatively. A policy concerned with keeping American markets viable for small firms would probably answer it affirmatively. Another novel issue is whether foreign competitors should be entitled to the same access. In the hypothetical, because some foreign firms have already spanned the adjacent markets, the need of others for access to the pool may not be evident. But I see no general basis on which an antitrust policy concerned about consumer welfare could exclude foreign competitors who are able to establish an essential facilities claim. ${ }^{146}$

Some of these issues may be involved in the recently announced

144. This fact may explain the Supreme Court's decisions that the exclusion of nonparticipants from information-sharing arrangements may amount to a Sherman Act violation. See Associated Press v. United States, 326 U.S. 1 (1945); United States v. Terminal R.R. Ass'n, 224 U.S. 383 (1912). On whether a firm possessing power must make available to competitors information they may need to compete, see Berkey Photo, Inc. v. Eastman Kodak Co., 603 F.2d 263 (2d Cir. 1979), cert. denied, 444 U.S. 1093 (1980). In any event, concerted action to share information that excludes some seems subject to the essential facilities doctrine.

145. "Dominate," as used here, is elliptical. Domination is signified not only by the firms" combined shares, but also by the extent of the advantage gained thereby. If sharing gives the participants a significant competitive edge, a claim for access is warranted.

146. Though most research and development is performed by individual firms, there are a number of R\&D joint ventures, some among competitors, and a few are quite large. See S. BERG, J. Duncan \& P. Friedman, JolNT Venture Strategies and Corporate InNovation 70-73 (1982). For example, Microelectronics and Computer Technology Corporation, one of the country's largest research joint ventures, includes as shareholders such companies as Control Data, Kodak, Boeing, and National Semiconductor. It also involves an investment of $\$ 600$ million in the work of 260 scientists. See Comment, The National Cooperative Research Act of 1984: A New Antitrust Regime for Joint Research and Development Ventures. 1 HiGH TECH. L.J. 133, 142 (1986). If a showing could be made that access to such a venture were essential to compete effectively in the American semiconductor market, I see no basis in law for excluding a company, in all other ways qualified, solely because it or its parent is organized in Asia or Europe. 
IBM-Intel Technology Sharing Agreement. ${ }^{147}$ IBM, using off-the-shelf chips in its circuitry, has faced aggressive "work-alike" personal computer (PC) competition, especially from Japanese manufacturers. The agreement with Intel gives IBM access to application specific integrated circuits (ASIC's), from which it can design hard-to-copy semicustom circuits. If IBM's ASIC designs cost more but performed no better than its existing circuits, we could infer that their purpose and effect was to exclude competition. Even if one assumes that IBM, acting alone, could legally change design at whim, that this exclusion was achieved concertedly would make it vulnerable under section 1 . That only Japanese imitators were excluded would not avoid the problem. Competition policy presupposes-indeed, depends upon - an adequate system for protecting proprietary innovations. But it does not countenance concerted conduct to harness innovation for an exclusionary, rather than a performance, objective.

If, as appears to be the case, ASIC designs improve performance, though at higher cost, the new venture widens the range of consumer options and alters the pattern of market competition. Presently, the IBM product is the industry standard; competitive effort is aimed at reducing price. Because imitative strategies are not possible in the new environment, the emphasis shifts to performance, though today's work-alike producers will remam free to offer low price PC's comparable to today's standard. An antitrust issue would remain only if, as appears not to be the fact, Intel alone had proprietary control of ASIC technology, and by contract it forbade IBM to supply or license others. ${ }^{148}$ Such an exclusive arrangement would present problems comparable to those encountered in a joint facilities case. If access to ASIC's is competitively important, IBM ought not to be permitted to foreclose that access to others through a contract with Intel.

\section{Joint Research}

Moving from shared technology to joint research yields different cost-benefit trade-offs. ${ }^{149}$ Complex market failures may affect the level of investment in innovation. An intellectual property norm that allows

147. See IBM, Intel Chip Away at PC Clones, San Francisco Examiner, Oct. 2, 1986, at C1, col. 2.

148. Cf. Berkey Photo, Inc. v. Eastman Kodak Co., 603 F.2d 263, 302 (2d Cir. 1979) (Kodak contracts with Sylvania and GE requiring them not to disclose to Kodak competitors information on flashcubes raised jury issue under section 1), cert. denied, 444 U.S. 1093 (1980); United States v. Standard Oil Co., 362 F. Supp. 1331, 1341 (N.D. Cal. 1972) (long-term supply contract precluding access by competitors of supplying firm violated section 3), aff'd, 412 U.S. 924 (1973).

149. The National Cooperative Research Act of 1984, 15 U.S.C. $\$ \$ 4301-4305$ (Supp. III 1985), assured qualified and registered $R \& D$ ventures rule of reason treatment and exempted them from treble damages, but did not otherwise alter antitrust norms. For a detailed review of the Act, see Comment, supra note 146. 
those not responsible for producing new information to use it could lead to economy-wide underinvestment in innovation. Reciprocally, legal rules that unduly protect innovators may cause too much capital to be invested in innovation and too little in current goods. ${ }^{150}$ These problems are intensified by the very existence of intellectual property rights, which allow the first to gain valuable information to exclude others, thus encouraging unduly large, duplicative investments in particularly visible areas of opportunity as firms race to be first, lest they be excluded..$^{151}$ The antitrust question is whether research collaboration by competitors can mitigate some of these failures and, if so, under what circumstances and at what cost?

Ever since Schumpeter, ${ }^{152}$ some commentators have insisted that large firms with market power are the incubators of innovation. ${ }^{153}$ Countless empirical efforts have attempted to confirm or deny this hypothesis or its alternative-that competition spurs innovation. Although the results have been inconclusive, they tend to suggest that medium-sized firms with noticeable but nondominant shares are frequently among the innovators. ${ }^{154}$ The argument for encouraging joint research does not draw directly on Schumpeterian theory, but accepts it as a congenial background. It claims, rather, that joint research makes accessible economies of scale, transaction cost benefits, and synergies without reducing competition.

This claim is speculative, however, because scale economics or synergies may or may not be available, and there may be offsetting costs in either case. For instance, a joint research venture reduces the incentive of each participant to engage in its own research because the venture reduces fear that the participating rival will outdistance it. Thus, the venture may result in lower total spending on research. Moreover, even if spending does not fall, the number and variety of research paths being explored may drop. A joint research organization that includes a large share of competitors may alleviate the tendency to race and thus facilitate a more balanced deployment of research resources. But Nelson and Winter see a tendency toward simplified bureaucratic decisionmaking in large-scale organizations - a style that often leads to parochial judgments

150. See Kaplow, The Patent-Antitrust Intersection: A Reappraisal, 97 HARv. L. Rev. 1813, 1825-26 (1984).

151. See R. Nelson \& S. WINTER, supra note 108, at 387-88; Kitch, The Nature and Function of the Patent System, 20 J.L. \& ECoN. 265, 266 (1977) (proposed awarding property rights earlier in the innovative process in order to reduce wasteful duplication).

152. J. SCHUMPETER, THE THEORY OF ECONOMIC DEVELOPMENT (1934).

153. For a thorough review of the literature on the relationship between firm size and innovation, see Kamien \& Schwartz, Market Structure and Innovation: A Survey, 13 J. EcoN. LIT. 1, 15-19 (1975).

154. Id. 
and less diversity in exploration. ${ }^{155}$ Assuming no change in total spending, there is no objective way to evaluate the impact on research outcomes of substituting joint for individual efforts; one knows only that results will differ.

Whether a given venture will reduce total research expenditures can be determined with more certainty. Such expenditures will probably depend on the strength of other incentives, such as foreign competition. It is important to know whether spending will go up or down, because research output seems to vary in proportion. ${ }^{156}$ Thus, a structural screen is again useful in judging the likely impact of joint research and development. Of course, reduced research expenditures may be offset by efficiency gains from cooperation. For example, cooperating firms may use scarce resources more effectively or avoid duplication of effort. Putting two effective researchers or research teams together may even result in economies of scale. But the existence of any of these benefits will be difficult to detect, let alone to quantify. If they are detectable at all, they should be reflected by a slight increase in the market share, signifying too great an impact on research competition. ${ }^{157}$

I am not proposing novel ways of analyzing research ventures. As yet, we know too little for that. Instead, I am urging adherence to conventional methods ${ }^{158}$ despite the recent tendency to view joint research as a solution to American economic ills. ${ }^{159}$ We know enough to recognize that joint activity in concentrated markets can reduce total research

155. R. NELSON \& S. WINTER, supra note 108, at 389.

156. Kamien \& Schwartz, supra note 153 , at 5-6.

157. Baxter, The Definition and Measurement of Market Power in Industries Characterized by Rapidly Developing and Changing Technologies, 53 ANTITRUsT L.J. 717, 723 (1984), proposes that an $R \& D$ joint venture with up to a $20 \%$ share of the relevant $R \& D$ market be regarded as benign. The European Economic Community cuts off its block exemption for joint R\&D at $20 \%$ of the associated applications market. Whether measuring by R\&D or applications market, one could probably go higher, perhaps considerably higher, though a court should always be open to explanations for a particular venture's perniciousness. The question is whether venture participants account for a sufficient share of the market to warrant slowing the pace of innovation. In most markets, that would probably require at least a $40 \%$ share. If, however, the venture controlled assets giving them an absolute cost (or other significant) advantage over outsiders, an essential facilities problem could arise at a much lower market share, even below $20 \%$.

158. There are three basic questions in analyzing any joint venture: (1) whether the cooperative (and hence noncompetitive) relationship among the venturers is unreasonable because it yields more risks of harm than promises of benefit (a question pursued through analyzing market definition, power, and changes in incentives); (2) whether collateral restrictions are unreasonable; and (3) whether access to the venture is reasonably necessary to enable outsiders to compete effectively and is unreasonably denied. See Brodley, Joint Ventures and Antitrust Policy, 95 HARv. L. REv. 1521, 1530-33 (1982). The analysis of an R\&D venture is a particular case of the general joint venture problem; it is more complex largely because the answer to the first question is often hard to determine. See ANTitrust Div., U.S. DeP'T of Justice, ANTITrust Guide Concerning RESEARCH JOINT VENTURES 6-7 (1980); P. AREEDA, supra note 22, at \367; M. HANDLER, H. Blake, R. Pitofsky \& H. Goldschmid, Trade Regulation 530, Problem 13 (2d ed. 1983).

159. See generally The National Productivity and Innovation Act and Related Legislation: 
output and facilitate cooperation in applications markets. But there is no credible case for treating all such ventures as unmitigated blessings. Joint research is not a mere cartel; its important functions are not limited to fixing the price and output for technology. Yet such a venture has some of the characteristics of a cartel. Like a cartel, it may have internal problems. Participants may try to give as little and take as much as possible. And, like some other cartels, it may succeed in constraining opportunistic behavior. But success may mean different things to the participants than to society. To ventures that represent a large share of a relevant research market, success may not mean producing and deploying new technical knowledge. As in the case of a joint sales agency, success may mean producing less and charging more.

Despite valuable insights from evolutionary and transaction cost economics, the most reliable test for evaluating joint research remains structural. There are difficult issues of market definition, of course. A safe procedure is to use the product market as an initial surrogate for the research market. ${ }^{160}$ The market should then be broadened to include other centers of like research if, but only if, the evidence clearly demonstrates that these alternative centers will provide the industry with a free flow of readily adaptable information. The ultimate judgment should be conservative. Yet, given its short-term and easy reversibility, a venture should be permitted somewhat denser concentration than would a merger between research units.

Assuming concentration large enough to threaten a merger, should the venturers be allowed to show efficiencies that offset the risks of harm? Regardless of how this question might be answered for a merger, an affirmative response is probably warranted here, subject to an important condition. Research is important, and efficient methods are to be prized. The risks of joint action, though real, stand only in the realm of probabilities. The condition I would add is that venturers must really prove the efficiencies; they must show explicitly and convincingly that they will be able to accomplish something jointly that they could not accomplish separately. ${ }^{161}$ The vague panegyrics one so often hears about joint research ought not to suffice.

If the research venture passes the structural test, its ancillary restraints must be examined. ${ }^{162}$ This inquiry should be pragmatic, not

Hearings on S. 1841 and on S. 568, S. 737 and S. 1383 Before the Senate Comm. on the Judiciary. 98th Cong., 1st \& 2d Sess. (1984).

160. This is the EEC approach. See supra note 158. It makes sense both because it is likely to be far more manageable and because competitive risks are likely to center in the applications market.

161. Such a showing might identify the particular market failures adversely affeeting $R \& D$ in the industry, provide credible comparisons of actual and promised levels of investment and research effort, and detail how the venture strategy can be expected to bring results closer to the ideal.

162. See Brodley, supra note 159, at 1531-32. 
hostile. It should recognize both that a research joint venture takes place in a world of bounded rationality and that it may well induce calculatedly misleading or opportunistic behavior among participants. ${ }^{163}$ If the venture is to be allowed, common sense suggests that participants should be permitted to design a structure that will limit opportunism and similar intrinsic difficulties, and thus increase the likelihood of the venture's success.

\section{Correcting Related "Market Failures"}

One problem encountered in technologically dynamic markets is "raiding"- hiring away a competitor's people for their innovative skill or their knowledge of important in-house information. Contract and tort law cannot fully protect against this behavior. Suppose a group of competing firms, unable to work out satisfactory standards for sharing research, agree instead not to hire any employee designated as a "protected" employee by her current employer. The arrangement may or may not threaten less harm than joint research, but it clearly promises less social benefit.

Competition policy is broader than antitrust; it includes private and public law regimes that protect investments, including investments in personnel. If present law makes raiding too easy, that law should be changed. But rules about when employers can bid for employees ought to remain social rules. They should be made by courts or legislatures capable of disinterested consideration of the social trade-off of employee mobility for personnel stability and continuity. Such "rules," effectively binding on a whole industry, should not be the creation of interested competitors who effectively formed a cartel with respect to the employment of technical personnel.

\section{Joint Production and Marketing}

Joint production and marketing move cooperation from the realm of information to that of application. This simplifies the analytical questions; they become more familiar. When a venture deals only with information, claims about the utility of cooperation are most credible and claims about resulting harms are hardest to document. When the venture starts making hardware and moving merchandise, it enters those parts of the economy where the nation has trusted competition most and been served by it best. The appropriate analysis for ventures of this kind

163. Some of the "free rider" problems built into an R\&D joint venture are suggested by the brief press report on the resignation of Admiral Bobby R. Inman as CEO of Microelectronics and Computer Technology Corporation. See Inman to Resign at M.C.C., N.Y. Times, Sept. 5, 1986, at D1, col. 3. 
is well developed and familiar. ${ }^{164} N C A A v$. Board of Regents confirmed the continuing legitimacy of this analysis.

\section{Cooperation Among Foreign Firms Entering American Markets or Encountering American Entry at Home}

\section{Cost-Cutting Activities by Foreign Firms and the "Disadvantage" Resulting from Antitrust Restraints on American Firms}

Suppose Japanese firms enter into a specialization agreement concerning steel production, an agreement that might be deemed a per se unlawful market division in America. ${ }^{165}$ Or suppose all Japanese chip makers agree to work on a single segment of a market-say, the 32-bit microprocessor-and to share information and divide developmental tasks. ${ }^{166}$ This agreement would be vulnerable under rule of reason analysis if it were among American firms of comparable size. ${ }^{167}$ Suppose further that either agreement yields efficiencies on products sold in competition with American products, that the Japanese participants price at their cost, and that consequently their shares grow while those of American firms shrink. Does an American competitor, losing its market share at home and abroad, have a cause of action? The answer ought to be no. If the foreign producer gets its product to market without subsidy at a cost-covering lower price, it ought to be making the sales. Any other answer grants too little to the interest of consumers.

Should American courts, then, put American firms on a parity with foreign ones? Should they, for example, hold that all specialization agreements are lawful when they reduce costs? It is possible, perhaps probable, that some cost-saving specializations would yield little or no market power, so that the savings, or at least part of them, would be reflected in consumer prices. One of the virtues of the implosion of per se and rule of reason analyses is that it allows a court to take a preliminary look at both the apparent purpose and basic structure of such arrangements. There is much in American case law that says market division is per se unlawful-and for good reason. But there is nothing in American law specifically holding that specialization is always per se unlawful. Thus, a characterization issue is presented.

If two small grocery chains, one in Queens and one in Nassau

164. See supra note 159 .

165. See United States v. Topco Associates, Inc., 405 U.S. 596 (1972).

166. This is apparently the strategy used by Japanese firms in developing the $64 \mathrm{~K}$ chip.

167. The two major American chip makers, Motorola Corp. and Intel Corp., have large shares of the microprocessor production in this country and dominate the market for microprocessors used in desk-top computers. It is expected that 32-bit chips will be a major factor in this submarket. Sce The 32-Bit Dash, San Francisco Examiner, Sept. 31, 1986, at D1, col. 2. Although potential competition from abroad would have to be considered, conventional analysis would certainly raise serious questions about the legality of Motorola-Intel cooperation in this submarket. 
County, agree on prices in order to facilitate joint advertising in a twocounty newspaper, would anyone call it per se price fixing? Why, then, should not a specialization agreement be subject to a similar analysis? Intent is important. If the problem they are really addressing is that competition has been forcing prices down to cost, then they are illegally dividing markets. But suppose their shares are very small and that fullline production requires short production runs that add to their costs, rendering them uncompetitive. Why not, then, call their accord a specialization agreement, subject to the rule of reason? If no participant has a sufficient share of a conservatively defined market to raise any serious risk that power will result, and if the specialization can be shown to yield real efficiencies, the arrangement is helpful, not harmful to competition. True, specialization might occur without agreement, but markets do not always work that well.

Suppose, however, that the participating American firms have more significant shares of their market. If GM, Ford, and Chrysler agreed to specialize, each in a segment of the car market, to meet foreign competition more effectively, the per se test should not, and is unlikely to be, abandoned. First, where shares are large, claimed efficiencies begin to sound like rationalizations; surely none of the big three auto firms have unduly short production runs on any significant part of output. Second, any possible efficiency gains would be swamped by the manifest risk of significant power concentration in the car market. Third, the increased concentration of each submarket increases the risk of international cartelization. If "market division" analysis (and consequent per se illegality) is the proper response to specialization by large firms in oligopolistic markets, and if "specialization agreement" rules (with consequent rule of reason legality) is the proper response to cooperation among a few small firms in a patently competitive market, the question becomes which characterization is proper in intermediate cases? That is, what if two or three smaller firms in a ten- or twelve-firm market agree to specialize in different submarkets? I would reserve the specialization characterization for instances where, on facial analysis, the risk of power is patently minimal. Otherwise, large numbers of market division cases might require full blown rule of reason hearings.

\section{Division of American Markets by Foreign Firms}

Let us now assume that two Japanese firms making the same products are about to enter the American market. Learning of each other's intentions, they meet and agree to split the American market geographically so that each can concentrate its sales and promotion effort. They also think that possible consumer confusion will be avoided if American 
buyers encounter only one Japanese firm. They split the market at the Mississippi River.

Some efficiencies are no doubt possible. Competitive harm will occur only if the agreement yields or increases power over price, and that will depend on the market or submarket share each participant garners. But although withholding judgment about legality pending a power analysis would not be irrational, it would be costly. Therefore, the per se response to such blatant horizontal market division is justified in this context as in others.

In the first place, markets are usually divided geographically to avoid or reduce competition. That is at least part of the reason here. To withhold condemnation pending a power analysis would entail a considerable expenditure of judicial and legal resources. It would also eliminate a bright legal line, and thus greatly increase the incidence of similarly risky arrangements. Moreover, the possible efficiencies, though not trivial, are likely to be slight. And it is anything but obvious that the firms seeking those efficiencies can obtain them solely by acting in concert. For instance, if either firm believes it can promote its products more effectively by entering only a part of the American market, it can make that choice unilaterally. If the first to enter starts in the West, the other, if of like mind, can start in the East. The absence of a prior agreement to specialize, however, leaves each firm as a potential entrant into the other's territory.

\section{Concerted Action by Foreign Firms in Their Home Markets That Inhibits American Entry}

Envision an American computer firm, perhaps the size of Burroughs. It creates, maintains, and provides software for computers designed to meet particularized needs-say, for firms in securities and commodities markets. It dominates this submarket in America and has a leading position in Western Europe. Recently, a European Economic Community (EEC) agency has financed, and the EEC Comnission has given antitrust clearance to, the formation of a joint venture among French, German, and English firms to exploit the same submarket, primarily in Europe. The venture, operating through a jointly owned and controlled subsidiary, is competitively aggressive. It persuades several European banks (all of which are ready to finance purchases of its products) to refuse to finance purchases of the American firm's products.

Assuming personal jurisdiction over the venturers, current American law ought to reach their foreign activities. United States $v$. Alcoa ${ }^{168}$ teaches that jurisdiction depends on intent to actually influence

168. 148 F.2d 416, 444 (2d Cir. 1945). But cf. American Banana Co. v. United Fruit Co., 213 
American commerce. Both the Alcoa test and the screen of the Export Trading Company Act ${ }^{169}$ seem to be met here. ${ }^{170}$ Of course, Timberlane Lumber Co. v. Bank of America ${ }^{171}$ and like cases ${ }^{172}$ raise a plethora of additional questions, most of them vague in contour.

In Timberlane, the Ninth Circuit held that although subject matter jurisdiction requires a showing that allegedly unlawful acts abroad had, or were intended to have, an effect on America's foreign commerce, a court may in some circumstances refrain from asserting its authority. ${ }^{173}$ It may consider the nationality, allegiance, and location of the parties; the relative significance of domestic and foreign conduct; the relative impact in America and elsewhere; the foreseeability of domestic impact; foreign law; and possible enforcement problems. After evaluating these and related factors, the court may decide whether the impact on American commerce is sufficient to warrant intervention. ${ }^{174}$ Given the Supreme Court's apparent desire to limit and structure judicial discretion in antitrust cases, it might reject the Timberlane approach if Congress does not intervene. Indeed, the Supreme Court's current disposition may be causing a drift away from Timberlane in recent lower federal court cases. ${ }^{175}$

But even under the judicial interest analysis of Timberlane, if the actual conduct supposed here is sufficient to violate the Sherman Act, the fact that it occurs abroad should not excuse it. EEC approval and financing of the venture surely are not enough to bring the venture's efforts to boycott the American firm under the Act of State doctrine. Those EEC involvements do not focus on boycott and therefore should not provide the venture with protection as a matter of comity. Evaluation of equity and fairness are implicit in the Timberlane test. As to these, the General Agreement on Tariffs and Trade (GATT) process seems relevant. Given present efforts to integrate the European and American markets, government-sponsored nontariff barriers to American participation in a European market would give the U.S. legitimate cause for complaint. That being so, I see no inequity or unfairness when America applies its own law to foreign conduct that significantly restrains America's foreign trade, especially when the challenged con-

U.S. 347 (1909) (anticompetitive collusion by American firms with Latin American governments held not subject to section 1 of the Sherman Act).

169. 15 U.S.C. $\$ \S 4001-4021$ (1982).

170. For a thoughtful discussion of the effects of the Act, see Shenefield, Export Joint Ventures, 54 ANTITRUST L.J. 1039 (1985).

171. 549 F.2d 597 (9th Cir. 1976).

172. E.g., Mannington Mills, Inc. v. Congoleum Corp., 595 F.2d 1287 (3d Cir. 1979).

173. 549 F.2d at 616 (upholding forum non conveniens dismissal).

174. See P. AREEDA, supra note 22, at $\Uparrow 191$.

175. See, e.g., Laker Airways v. Sabena, Belgian World Airlines, 731 F.2d 909 (D.C. Cir. 1984) (upholding an injunction against a parallel foreign proceeding). 
duct would likely violate EEC antitrust law if the target were an EEC firm.

That leaves, then, only the substantive antitrust question: Is the per se boycott rule appropriate where foreign firms at the same horizontal level act concertedly to foreclose an American competitor from inputs or customers important to its success? In my judgment, the per se rule would unquestionably cover such conduct if it occurred in America. However, the jurisdictional inquiry, even under an unreconstructed Alcoa analysis, requires some showing of competitive impact. That fact, and the concern for comity, suggest that a boycott on foreign soil be subject to at least a truncated rule of reason analysis. ${ }^{176}$ Yet, exhaustive inquiry as to the boycott sponsors' market power seems unnecessary. Under Justice Stevens' conception, that inquiry should end at the point where the court can give a confident answer-here, as soon as it appears that the venturers may be able to impact their submarket significantly. Application of a structural screen, perhaps one based on the JoskowKlevorick proposals, ${ }^{177}$ to the relevant submarket should suffice to resolve the question.

No doubt application of the Sherman Act to foreign conduct with the vigor suggested here would further strain relations between America and some of its trading partners. ${ }^{178}$ A desire to avoid such strain motivates the Administration's proposal that Congress enact an elaborate version of the Timberlane analysis as a new jurisdictional test. ${ }^{179}$ In that proposal, the State Department's concern for smooth relations with trading partners seems to have dominated any concern for American economic interests, which should be defended by the Department of Justice and the Department of Commerce. I am not arguing that the matter is settled by Alcoa. The extent to which old law can claim current adherence depends in part upon the stability of the social and economic conditions to which that law applies, and I have been stressing the rate and significance with which economic and political change is affecting international trade.

I urge adherence to Alcoa not because conditions now resemble those of the war climate in which Alcoa was decided, but because the

176. This view is consistent with the U.S. DEP'T OF JUSTICE ANTITRUST GUIDE For INTERNATIONAL OPERATIONS 53-59 (1977).

177. Joskow \& Klevorick, supra note 133.

178. The strain is both stressed and documented in the symposium published under the generic caption, Jurisdictional Conflicts Arising from Extraterritorial Enforcement, 54 ANTITRUST L.J. 711 838 (1985); see also Stanford, The Application of the Sherman Act to Conduct Outside the United States: A View from Abroad, 11 CORNELl INT'L L.J. 195 (1978); cf. Rio Tinto Zinc Corp. v. Westinghouse Elec. Corp., [1978] 2 W.L.R. 81 (upholding in part an order compelling production of evidence to aid American judicial proceeding).

179. Foreign Trade Antitrust Improvements Act of 1986, Special Supplement, [Jan.-June] Antitrust \& Trade Reg. Rep. (BNA) No. 1253, at S-14 to S-15 (Feb. 20, 1986). 
Alcoa test would most effectively serve American interests today. America might well have taken a self-effacing attitude toward applying the Sherman Act to foreign conduct when America's balance of payments was of no great concern. But in a world where economic integration goes on apace, America ought to be much more aggressive in seeing that foreign segments of the integrated world market are not rigged in ways that violate American law, batter American economic interests, and distort the international efforts to facilitate trade-efforts to which this country and its trading partners are firmly committed.

No doubt the State Department has a role in addressing these problems. Diplomatic efforts are needed and compromise with trading partners may be inevitable. But those engaged in diplomacy need a clear sense of direction. They should encourage international efforts to break down privately constructed trade barriers, not insulate such barriers from American antitrust law.

\section{International Markets and International Cartels: The Act of State Problem}

Looking further ahead, perhaps to the year 2000, let us speculate that the center of gravity for the international market in automobiles has shifted from the United States to Japan. Overproduction is rampant. World production-encouraged in several countries by subsidiesremains high even though inventories are large and current production of the popular models is almost enough to replace all existing vehicles in three years. A vast number of used cars overhangs the market.

MITI calls an international conference to discuss these problems. Representatives of producers (primarily private companies but some government-owned firms as well) from all western countries attend, as do representatives from several governments, including observers from the United States Department of Commerce. Over the course of two years of open meetings, a detailed "voluntary plan" is developed to reduce and allocate production in a manner reflecting plant capacity, efficiency, and social need. MITI structures the plan on the basis of information, suggestions, arguments, and indications of potential consensus that emerged during the meetings. MITI announces that Japanese firms will comply with the plan's reductions and urges all other producers to do the same. During the following months, most producers announce that they will do so.

Consider the American antitrust liability of participants-including participating American firms-under conventional analysis. There are exemption issues and liability issues. MITI, the sponsor, and other participating governmental missions would likely gain protection under the 
Foreign Sovereign Immunities Act of 1976 (FSIA). ${ }^{180}$ MITI and similar participants are not themselves producers, and their interests are primarily, if not entirely, governmental. Thus, their activities would probably not be deemed commercial, and they would consequently retain their immunity. MITI and other government missions would also have Act of State exemptions. ${ }^{181}$ Many others-certainly the socialized producers, and probably any private producer with governmental direction or encouragement-might also gain exemption under that doctrine, ${ }^{182}$ although the FSIA might be read to imply a commercial activity limitation on this exemption. ${ }^{183}$ Yet, some participants, American firms among them, could not make a plausible claim for Act of State protection. Consider, for example, the firm that makes cuts at a plant located in a country that does not officially sanction the international plan (especially if that country, like America, has a consumer-oriented competition policy that is hostile to the plan). The Act of State exemption would not protect such a firm merely because other states have directed other firms to participate.

The distinctions I have drawn between governmental and private action depend on a conventional analysis. Is such an analysis proper? Is the distinction between commercial and governmental conduct, however conventional in an American setting, culturally realistic when applied to activity, say, in Japan? ${ }^{184}$ If a socialized firm gets caught by a commercial limitation upon the judicially developed Act of State doctrine--a distinct possibility-should not MITI lose its protection as well? After all, that agency is performing resource allocation and related functions that would be private commercial functions in a thoroughgoing market economy; in Japan, as in some European countries that engage in indicative planning, the line between public and private activity is far less vivid than in America.

Another exemption issue concerns whether residual, nonexempt producers should be liable if most participating producers gain Act of State protection. Arguably, both fairness and the effectiveness of the Act

180. 28 U.S.C. $\S \S 1330,1332,1391,1441,1602-11$ (1982). See Hovenkamp, Can A Foreign Sovereign Be An Antitrust Defendant?, 32 SYRaCuSE L. REv. 879 (1981).

181. Case law supporting and explaining the Act of State Doctrine includes Banco Nacional de Cuba v. Sabbatino, 376 U.S. 398 (1964); Underhill v. Hernandez, 168 U.S. 250 (1897); International Ass'n of Machinists and Aerospace Workers v. OPEC, 649 F.2d 1354 (9th Cir. 1981), cert. denied, 454 U.S. 1163 (1982).

182. See, e.g., Timberlane Lumber Co. v. Bank of America, 549 F.2d 597, 606.08 (9th Cir. 1976).

183. See W. ANDERSEN \& C. Rogers III, supra note 9, at 925.

184. See E. Vogel, Japan As Number ONe: Lessons for America (1979); C. Johnson, MITI ANd the Japanese Miracle: The Growth of Industrial Policy 1925-75 (1982). Both books stress the aspects of Japanese culture that lead to a high integration of business and governmental decisionmaking in Japan. 
of State exemption require that the exemption run to the cartel as a whole. The fairness point is obvious enough. The effectiveness argument states that successful antitrust enforcement against even a few producers could frustrate the whole cartel; the participants forced out of the cartel by American antitrust action would start expanding their output. Enforcement action in this situation would be tantamount, economically, to an injunction against the entire cartel.

The fairness argument ought to fail for two reasons. First, forbidding a firm from participating in a cartel lawfully open to its competitors hardly does the nonparticipant unrelenting harm. Cartel participants become less aggressive competitors; the nonparticipant can hope the others will be faithful to their commitments so that a price cut will yield it an expanded share. If the cartel collapses because some firms cannot participate, all firms will be on a par following the collapse.

The effectiveness claim ought also to fail, though for reasons that are ultimately matters of value preference. The effectiveness argument asserts that not applying American law against firms sheltered by a foreign state requires that American law not be applied to other firms not so sheltered-indeed, not even to an American firm acting in America. If one assumes, as I do, that American antitrust law constitutes an expression of important American economic values, the policies that support an Act of State exemption do not call for the self-effacement that legalizing the international cartel would entail.

There remain, of course, issues of liability. Assuming there are some nonexempted participants, is the cartel unlawful per se? If not, is it justified under the rule of reason? Under traditional doctrine it would certainly be unlawful per se for American firms (or others) concertedly to reduce output in American plants. Nothing in the recent case law impeaches this conclusion. As to the liability of nonexempt firms reducing output abroad, the Export Trading Company Act requires (as might well be required independently of that Act) showing an effect on America's domestic or foreign commerce. Under either a per se or rule of reason approach, once that effect is established, either theoretically or empirically, the inquiry should end. ${ }^{185}$

Absent legislative change, is there any argument that such cartel participation by nonexempt firms does not violate American law? The only argument I see would be an assertion based on Appalachian Coals ${ }^{186}$ that what was good for the American economy in the 1930's will be good for the world economy in the 2000's. But that contention would over-

185. See supra note 177 and accompanying text.

186. Appalachian Coals, Inc. v. United States, 288 U.S. 344 (1933) (local price-fixing cartel did not violate Sherman Act because it did not threaten to reduce competition in the national coal market). 
state a case that, even narrowly construed, has never been notably persuasive. Moreover, in contrast to the Court's conclusion in Appalachian Coals, ${ }^{187}$ I assume here that an effect on commerce can and would be shown.

\section{E. Maintaining Competition in Deregulated Markets}

Deregulation, like foreign activity, had a great impact on American markets. In financial markets, all of the old market divisions are fading. Firms in each segment, familiar with their own problems, look wistfully at adjacent segments, where the problems are less obvious to them, and conjure expansion strategies. Meanwhile, they may act concertedly, hoping to protect their own conventional turf. Similar developments can be seen in the air, rail, and road transportation industries. Consolidation and cooperation are both evident.

The overhanging risk is that deregulation may end in noncompetitive market structures. That possibility seems particularly great in the airline industry, even though deregulation has already yielded some of the performance improvements expected from competition. ${ }^{188}$

Before the Airline Deregulation Act (ADA), ${ }^{189}$ "trunk" airlines carried about ninety percent of domestic traffic. After the Act, the trunks' share fell to about seventy-four percent, though the share of the two leaders remained close to pre-ADA levels. Hub and spoke configurations were extended and rationalized. ${ }^{190}$ Governmental inquiry generated information about strategies used in the new environment, ${ }^{191}$ and eleven airlines raised antitrust allegations in a suit filed against United and American. ${ }^{192}$ To raise relevant issues I will make several assumptions. ${ }^{193}$

187. Id. at 373 .

188. See U.S. General AcCounting Office, Deregulation: InCREased Competition Is MAKing Airlines More Efficient ANd Responsive to Consumers (1985). Important as it is to this thesis, I pass over the wave of airline mergers to focus on allegedly concerted or interdependent strategies of a kind I have more than once encountered in consulting.

189. Airline Deregulation Act of 1978, Pub. L. No. 95-504, 92 Stat. 1705 (1978).

190. This pattern of routes, incidentally, intensifies safety problems because all carriers serving a hub try to arrive near peak hours to facilitate interconnection. Concerning post-ADA structurc and conduct, see E. Ba1ley, D. GrahaM \& D. KaPlan, Deregulating the Airlines (1985); Call \& Keeler, supra note 94; Kaplan, The Changing Airline Indistry, in REGULATORY REFORM: WHAT ACTUALly HaPpened 40-78 (L. Weiss \& M. Klass eds. 1986).

191. Review of Airline Deregulation and Sunset of the Civil Aeronautics Board Before the Subcomm. on Aviation of the House Comm. on Public Works and Transportation, 98th Cong., 1st Sess. 27-122 (1983) (report to Congress on airline computer reservation systems prepared by the Civil Aeronautics Board in consultation with the Department of Justice); U.S. GENERAL ACCOUNTING OfFice, Airline COMPetition: IMPACT OF COMPUTERIzed Reservation SYSTEMS (1986).

192. USAIR v. American Airlines, CV No. 84-8918-ER(TX) (C.D. Cal. filed Nov. 20, 1984).

193. My interest here is not to resolve disputed factual issues, but to consider whether current antitrust law would be adequate to maintain airline competition if the most threatening view of the 
Assume that United and American, with respective shares of twenty and fourteen percent, have an absolute advantage in start-up promotion costs over smaller lines. This advantage is especially pronounced when former local service, regional, intrastate, or charter carriers enter new city-pair markets. United and American have national recognition and reputation. Consequently, they can hold fares above competitive levels in city-pair submarkets where competitive entry has not yet occurred, and can even maintain fares higher than that of less well-known carriers for a substantial period after its entry. In some respects, the two act as rivals. In others, they coordinate. Often, they achieve coordination without coinmunicating except by market moves. Sometimes, however, they must and do communicate-if only through indirect, sanitized means.

A central feature of their interdependent strategies is vertical integration with travel agencies. This is currently achieved through computerized reservation systems (CRS); each carrier provides CRS terminals to travel agents on long-term contracts with significant termination penalties. American and United dominate the CRS market, with a combined share of about seventy percent, and each has obtained substantial market power through CRS. They charge travel agents for CRS service. Agents, however, need only one service and are not locked into any particular CRS except by contractual provisions. An agent could thus switch from American's CRS to United's or could choose an alternative service. But United and American also charge competing airlines to list flight information on their CRS's. Unlike travel agents, competing airlines cannot shop for alternatives; in order not to lose bookings, they have to be listed on every CRS system that has any significant share of the market. The provision of CRS listings to competing airlines thus assures both United and American of market power.

United and American use this power to enhance their positions in the airline transportation market. At first, they used blatant biases in CRS screen displays of alternative flights and fares. This gave them substantial "incremental revenues" as air carriers-a monopoly return from CRS ownership. Before its sunset, the Civil Aeronautics Board (CAB) forbade blatant bias and also ordered nondiscriminatory CRS pricing. The two carriers responded to the CAB order in two ways. First, they employed more subtle biases in the form of delays or inaccuracies in entering new information from competitors, and listing order hierarchies based on biased (though seemingly objective) criteria. Second, and more importantly, they raised prices for competing airlines, increasing listing costs 250 to 500 percent.

facts were accurate. From this point on, therefore, I build a hypothetical that draws on material from the government reports and allegations in the pending lawsuit. 
Assume that to achieve coordination on this pricing move, it was necessary for United and American to communicate. They met-but not, ostensibly, to agree upon what to charge their competitors. Instead, they met for the stated purpose of negotiating what each would charge the other. They did this under the shadow of the CAB order. Each knew that whatever prices they applied to each other would, under that order, apply without discrimination to their competitors. Consequently, all listing airlines were obliged to pay an amount vastly higher than any rival airline had previously been charged, an amount approximately sufficient to offset the incremental revenues previously obtained by display bias, but lost under the $\mathrm{CAB}$ order.

Under these assumed facts, have United and American violated section 1? But for the negotiation of listing charges, coordination theories about American and United would echo those in E.I. du Pont de Nemours \& Co. v. FTC. ${ }^{194}$ There, Judge Mansfield of the Second Circuit held that coordinated conduct of competitors did not violate section 5 of the FTC Act merely because their strategies resulted in a less competitive market. Absent evidence that this competition-injuring coordination was achieved through an agreement, one ordinarily would have to show that each participant had adopted the challenged conduct for anticompetitive purposes. However, in the airline hypothetical, the negotiation between American and United opens additional analytical options.

Why did not United and American, each acting independently and giving full recognition to its own position of power, decide what it thought its CRS product ought to yield and set its own price? Each had always done so previously and continued to do so for travel agents. If either thought it needed information on user reactions to prices, why did it not survey several users, or at least negotiate with a user that did not have its own CRS system? Why did each turn to the only other firm for which a coordinated CRS price would be of strategic interest? These kinds of questions raise issues about the characterization of the UnitedAmerican negotiation. In my judgment, the minimum appropriate legal response would be to instruct a jury that the Sherman Act was violated if the participants entered into the negotiation with the purpose and effect of coordinating the prices each would charge to others. I would go even further and instruct a jury that a finding of the facts hypothesized here should compel a conclusion of conspiracy.

194. 729 F.2d 128 (2d Cir. 1984). The listing charge for CRS-which, so long as two airlines remain dominant, has an "essential facilities" aspect-may well be driving the current consolidation movement in the airline industry, a movement that makes it possible for smalier firms-at least, given a decade or more within which to react-to offset American and United CRS charges with CRS systems of their own. 


\section{F. Maintaining Competition Among Intrabrand Rivals}

\section{Concerted Action to Create and Promote a Brand}

Effectively stated theoretical perspectives ${ }^{195}$ and some judicial responses to them ${ }^{196}$ have altered (Chicago commentators would say "deregulated") the law of vertical restraints. The inquiry here is whether analogous changes are called for when intrabrand competitors cooperate horizontally. ${ }^{197}$

Consider the following hypothetical. Forge Steel Co. makes hardware products in competition with other manufacturers. It sells to retailers through distributors. Smith, a retailer, recruits nine or ten other dealers in the East Bay, her metropolitan area, into an association. They adopt the name Hi-Valu Stores, follow common marketing policies, and advertise as a unit in the metropolitan press.

So far there is no concern. The firms are acting jointly to gain integration benefits. They have trivial shares of any possible resale market. They could merge, and surely they may engage in less intensive cooperation. Suppose, however, that they set selling prices cooperatively, in apparent violation of the per se rule. If they do so merely to facilitate joint advertising, the conduct ought to be unobjectionable, given their manifest lack of power. Indeed, there is an additional justification-the brand identification reinforced by their ads may enhance interbrand competition.

Now, suppose the participants agree to divide territories, with each to be responsible for a specified level of Hi-Valu promotion in its area. Under United States v. Topco Associates, ${ }^{198}$ such a division is unlawful per se. Topco probably ought to end the discussion, even if one believes, as I do, that Broadcast Music and NCAA open the possibility of "characterization defenses" to market division as well as to price fixing. ${ }^{199}$

195. E.g., O. Williamson, supra note 127.

196. E.g., Jefferson Parish Hosp. Dist. No. 2 v. Hyde, 466 U.S. 2 (1984) (rule of reason analysis applied to allegations of tying); Continental T.V., Inc. v. GTE Sylvania, Inc., 433 U.S. 36 (1977) (discarding per se rule against geographically restrictive franchise agreements in favor of rule of reason analysis).

197. The U.S. Department of Justice Vertical Restraints Guidelines not only gave radically excessive readings to the recent vertical restraint cases, but asserted that all single brand restraints should be characterized as vertical, so as to escape the legal norms that apply to horizontal restraints. This strategy, a manifest effort to make new law, was harshly criticized and rather weakly defended in oversight hearings. See The Oversight Of Department of Justice's Vertical Restraints Guidelines: Hearing Before the Senate Comm. on the Judiciary, 99th Cong., 1st Sess. 15-29 (testimony of Charles F. Rule, Acting Assistant Attorney General, Antitrust Division). The Justice Department's excesses make it difficult to address the questions raised here in a balanced way, but the task should be attempted.

198. 40 S U.S. 596 (1972).

199. See the analysis suggested by M. HANDleR, H. Blake, R. PITOFsKY \& H. Goldschmid, supra note 22, at 340 , Problem 8 . There is nothing problematic about the Topco result when it 
Those cases stress the importance of analysis focusing on less restrictive alternatives and on leaving independent avenues open when common roads are taken. Here, some division of responsibility for promotion is an appropriate ancillary restraint; without it, free rider concerns might unduly limit promotion by participants. But surely an airtight territorial restriction is not the least restrictive way to overcome this free rider problem. ${ }^{200}$ Contributions to a common fund or bilateral commitments by each to expend designated sums would be adequate. Even if a degree of territorial separation is thought useful to assure sufficient coverage for brand-oriented customers, the venturers need not lock each participant entirely out of the others' areas. "Primary responsibility" or "pass-over" arrangements are familiar alternatives, and others could be developed that would also adequately meet any legitimate need.

Is all this too strained an effort to preserve Topco? I think not. On the Hi-Valu facts, the likelihood of competitive injury approaches triviality, and any concerns that participants will be coerced are, if not trivial, at least small. Not all cases will be so trivial, however; some will be at or near the middle of the bell curve of possible competitive risk. The value of per se analysis is that it spares the legal system the cost and strain of strugghing with such cases. Where, as here, less restrictive and at least substantially as efficient ways of obtaining the relevant benefits are immediately identified, inquiry should stop.

Creating and promoting a brand will justify many horizontal arrangements. But joint promotion does not make airtight territorial restraints essential, even if it sometimes allows joint price setting. In the former instance, benefits may be obtained by less restrictive means; in the latter, they sometimes cannot.

\section{Joint Bargaining with Suppliers}

Suppose Hi-Valu dealers, seeking to bypass distributors, appoint Smith to negotiate with Forge Steel about the prices at which Forge will supply the venture. ${ }^{201}$ Joint price setting is once again involved, but this time for purchase rather than selling prices. The alleged efficiency justifications would be based on reduced transaction costs and better information deployment. How significant such efficiencies might be is not immediately obvious. Do participants have monopsony power when acting concertedly to buy? It is conceivable, perhaps, but unlikely.

applies to purely horizontal market division. The characterization issues arise only when, as in Topco itself, the restraint has a vertical (or intrabrand) as well as a horizontal dimension.

200. Cf. Pitofsky, The Sylvania Case: Antitrust Analysis of Non-Price Vertical Restrictions, 78 COLUM. L. REv. 1, 28-31 (1978).

201. Cf. Smith v. Pro Football, Inc., 593 F.2d 1173 (D.C. Cir. 1978) (sustaining, in part, an antitrust challenge to the NFL's draft system). 
A per se analysis here would not be surprising, but I think the solution best in keeping both with modern economic theory and recent case law is recognizing that on the issue of coercion, this problem stands close to the margin between Broadcast Music and NCAA. The result must turn on the particular facts. First, Broadcast Music implies that even when concerted actors have power, joint price making can be justified if the benefits are substantial and the activity is not coercive-at least if the firm on the other side of the bargaining table exercises comparable power. ${ }^{202}$ Second, $N C A A$ establishes that even if significant integration efficiencies are obtained, and those cooperating have not been shown to possess market power, concerted price setting does violate section 1 if reluctant sellers are compelled to participate.

Our hypothetical turns, then, on the central question of coercion. Must dealers participate in the joint negotiations in order to continue as Hi-Valu participants? If not, Broadcast Music and $N C A A$ could be read to mean that the joint activity can be justified by a credible showing of transaction costs and information efficiencies. ${ }^{203}$ This is probable in the hypothetical since it is doubtful that the dealers exercise significant power as hardware buyers.

There could, of course, be a power issue. ${ }^{204}$ If the appropriate market is the East Bay, Hi-Valu participants may represent a significant portion of the market and market power might be shown to exist. If so, that fact ought to outweigh evidence of efficiencies short of a showing that, like that in $B M I$, is so profound that the efficiency attained can fairly be characterized as creating a new product. Certainly the law should not countenance GM, Ford, and Chrysler bargaining jointly for steel merely because doing so would enable them to cut back their individual purchasing departments. If real power is attained through joint bargaining, any efficiency gains are likely to benefit the monopsonists, not the consumers.

There is another coercion issue here that is related to, but distinct from, market power. It is the possibility of coercion on Steel Forge, rather than on the retailers, to grant the latter's terms. Bargaining always entails an inplicit assertion by participants that if they do not coine to terms they will part. When an agent bargains for a collective of separate firms, however, there is an ambiguity. If the joint negotiation fails, will some or all of the represented firms return to the table on their

202. Although not stressed in the opinion, Broadcast Music involved firms with comparable bargaining power. See supra text accompanying note 69.

203. These efficiencies should not be assumed. Proponents should be under some obligation to establish that they are real. But this does not mean that an open-ended rule of reason hearing is necessary. Unless the facts are less one-sided than appears, the efficiency issue might be disposed of through a summary proceeding.

204. Once again, summary proceedings might be sufficient if market shares prove to be particularly low. 
own? When retailers jointly bargain, may they (assuming lack of market power) threaten Steel Forge with a concerted refusal to deal if agreement is not reached? Using labor language, may they "strike" or "boycott" if they cannot obtain satisfactory terms?

To resolve this question, I rely on instinct and a sense of history rather than on economics. If each Hi-Valu firm has remained free, throughout, to deal on its own, I see no basis for finding coercion. But if those that authorize the agent to deal with the supplier also commit themselves to walk away concertedly if no deal is struck, I would hold their conduct unlawful, regardless of their market power. The practice of joint bargaining always brushes up against the price-fixing per se rule. When it also involves a strike threat, it concerns the boycott per se rule as well. Where power is lacking, the allowance of price fixing may be justified by the efficiencies yielded by the arrangement. But those efficiencies do not turn upon the ability of participants to threaten concerted action when bargaining is unsuccessful.

\section{Joint Activity in the Franchise Context}

Let us now turn to a different hypothetical. Fry, a national fast food chain, grants franchises only to tenants that lease retail premises owned by Fry and developed in accordance with its specifications. ${ }^{205}$ Franchisees pay rent, an annual franchise fee, and a specified percentage of gross retail sales. Franchisees also agree to purchase specified products only from Fry. ${ }^{206} \mathrm{~A}$ few years ago, a class action was brought against Fry by franchisees challenging the leases and the purchase terms as an illegal tying arrangement. Fry was awarded summary judgment under Jefferson Parish Hospital District No. 2 v. Hyde. ${ }^{207}$ Fry has just received notice that several of its franchisees have appointed Smith as their bargaining agent. Smith notifies Fry that franchisees demand the following contract modifications: an option for each franchisee to purchase its rented premises at fair market value; a reduction in the part of the franchise fee based on revenue; and replacement of the product purchase requirements with product specifications. Fry and Smith negotiate and reach agreement congenial to the franchisees in each area.

Under traditional horizontal doctrine, joint bargaining leading to agreement on any of these items would be suspect. In the case of the price term, such bargaining-and certainly agreement-might well be

205. Cf. Principe v. McDonald's Corp., 63I F.2d 303 (4th Cir. 1980) (linking fast food franchise to leasehold held not to constitute illegal tying), cert. denied, 451 U.S. 970 (1981).

206. Cf. Siegel v. Chicken Delight, Inc., 448 F.2d 43 (9th Cir. 1971) (requiring fast food franchises to purchase equipment, food, and trademark held to be an illegal tying arrangement), cort. denied, 405 U.S. 955 (1972).

207. 466 U.S. 2 (1984). 
classified as unlawful per se. Can modern facial analysis lead to a characterization defense that would assure rule of reason treatment? If so, how should the case be analyzed? Here, as in the hypotheticals discussed above, the question is, in a sense, whether intrabrand horizontal analysis ought to be patterned on vertical analysis. The basis for applying rule of reason analysis to vertical restraints is that these arrangements can yield transaction cost efficiency that warrants the costs of full analysis. This joint bargaining by downstream firms with a common supplier is justified by a reciprocal claim of efficiency; that is, both sides may claim that joint bargaining deploys information widely and efficiently, reduces costs by substituting one transaction for several, and may bring ultimate outcomes closer to the competitive ideal by substituting one real bargain among equals for a series of "take it or leave it" transactions between one competent and informed negotiator and a series of "knowledgeless inepts." While one could reject these contentions, they are, in general, as forceful as those made to defend vertical restraints.

Let us begin by putting aside explicit bargaining of prices and consider instead the tying requirements. Regardless of the correctness of the Ninth Circuit's view that a franchise may be a tying product, ${ }^{208}$ under current law a tying arrangement is legal unless the franchisor has power in an appropriately defined franchise market. ${ }^{209}$ The argument seems fairly compelling that if Fry can lawfully impose this tie because it lacks market power, then its franchisees, when bargaining concertedly, must also lack power. Therefore, although deprived of the protection of the per se tying rule, the franchisees ought now to be able to protect themselves against the tie by acting concertedly. Transaction cost and information economics quickly indicate efficiencies; the power analysisborrowed, as it were, from the implications of the franchisor's own conduct-shows whether there is market power sufficient to warrant frustrating these efficiencies.

Possible counterarguments are based on the fact that Fry must be taking some of its reward for the franchise through the ties. The first is that, consequently, joint bargaining about the tie is price fixing, a per se violation. But this argument is "estopped," in a metaphorical sense, by the fact that the tie itself is presumptively legal. Just as the powerless franchisor's decisions about the form in which it will take its reward are said to be socially inconsequential, so must be the countermoves of its powerless franchisees. It may not look this way to the parties, but from the vantage point of the theory that justifies the tie, the agreement these negotiators forge is of little or no consequence to any but themselves.

The second counterargument is that forbidding the tie would pre-

208. Siegel, 448 F.2d 43.

209. Jefferson Parish, 466 U.S. 2. 
clude not only price discrimination, but the beneficial results of that discrimination as well; that is, it would prevent extensive deployment of the trademark and name to those who are interested and willing to pay a fee to use them. This argument here, and in most instances, is probably vulnerable on the facts. Ties are not the only (or even the most efficacious) metering device available to the franchisor. Fry also takes a percentage of gross sales; if it cannot meter through the ties, it can meter in this way. In any event, the lack of power presumed from the legitimacy of the ties tends to trivialize the significance of wider dispersion of this particular franchise, just as it trivializes the significance of its price. Would-be franchisees have a wide range of options. If the negotiation leads to a nondiscriminatory franchise fee too high for some marginal franchisees to pay, they have many market alternatives.

\section{Resale Price Fixing By Franchisees}

Does the above analysis lead to the position taken in the Vertical Restraints Guidelines-namely, that, subject to screens that would catch few, if any, harmful transactions, single brand competitors should be free to divide markets and fix prices whenever it is profitable? ${ }^{210}$ Of course not. Where horizontal competitors are dividing markets or fixing prices, the potential for harm is so great and that for benefit so trivial that a per se response is plainly warranted. In their approach to issues conventionally regarded as horizontal, those guidelines exemplify theoretical excess.

\section{CONCLUSION}

There are varieties of modern thought-political, sociological, economic, humanistic. To be worth reading, an antitrust opinion, like any thoughtful essay, must take shape and color from one or more of these sources. It is, after all, an act of governance, of dispute resolution. Solomon is probably a better model for the antitrust judge than is Hobbes. A notably successful antitrust opinion both explains a particular world of business and makes national competition policy appear as a seamless unity. But we should not take lucidity and simplicity for inevitability, nor should we blind ourselves to the imagination that lies behind the opinion.

A common flaw in antitrust criticism, one I have no doubt shared, is a tendency to take the categories a judge has used to explain her thinking as though they were real world constructions, and thus rightly or wrongly perceived. They are not. Categories and definitions are ways of imposing enough order on phenomena to make further thought and explanation possible. A judge choosing among possible ways to charac-

210. See supra note 199. 
terize a transaction is engaged in serious business-the choice will signify much about her attitudes as they take shape. Her choice is important for that reason, and not because one characterization is right and another wrong. Indeed, several different characterizations may result even from one judge's particular set of attitudes. At most, one characterization will be more convenient than the others.

Market definition provides a familiar example. After viewing data relevant to competitive effect, a judge might speak of a national market or an international market. No substantive point she might wish to make-and no conclusion she might ultimately reach-would be foreclosed by either definition. In that sense, the choice is trivial. But by the time she defines a market, the judge has been exposed to the industry and has developed attitudes about its competitive problems and opportunities. When she selects one market definition or the other, she reveals her mode of analysis and signifies the insights she intends to stress, thereby narrowing the range of future choices open to her.

Something similar occurs when a judge chooses between a per se rule and the rule of reason. Making this choice does not so much limit the factors relevant to the decision as indicate how elaborate an inquiry is thought necessary to reach the right result. In its recent horizontal restraint opinions, the Supreme Court has been more articulate about (and probably more conscious of) this characterization processes. It has not seriously attempted to make everything seem inevitable. The Court has also avoided sweeping commitments to any single theoretical or ideological perspective. All this is to the good. The antitrust tradition approaches its centennial in reasonably good condition. This is due as much as anything to the fact that over the last century the Court has seldom written too large. It has tried to solve the problems at hand, solidifying as well as building upon what it has done before.

Neither the Court nor those of us who watch it can foresee the econonic problenis of the next century, nor even of the next decade, let alone predict what theories will be available and what values will be ascendant a generation hence. But the law can be kept in repair. It will be best fitted to new situations and concerns if it develops in a slow and orderly way-if adaptations in the law are made only as needed to neet problems now at hand, problems that we understand reasonably well. 
